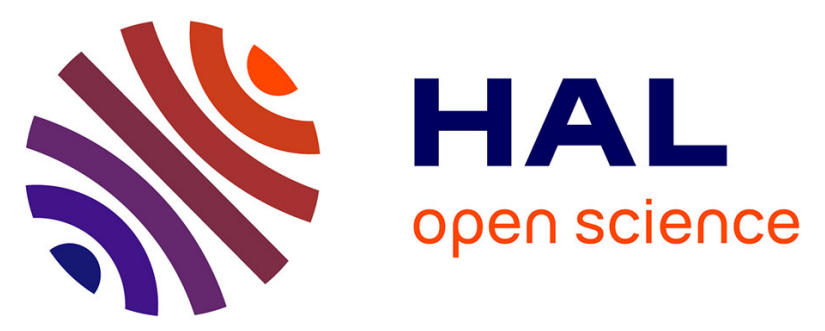

\title{
Landslide susceptibility mapping of Cekmece area (Istanbul, Turkey) by conditional probability
}

\author{
T. Y. Duman, T. Can, C. Gokceoglu, H. A. Nefeslioglu
}

\section{To cite this version:}

T. Y. Duman, T. Can, C. Gokceoglu, H. A. Nefeslioglu. Landslide susceptibility mapping of Cekmece area (Istanbul, Turkey) by conditional probability. Hydrology and Earth System Sciences Discussions, 2005, 2 (1), pp.155-208. hal-00298621

\section{HAL Id: hal-00298621 \\ https://hal.science/hal-00298621}

Submitted on 19 Jan 2005

HAL is a multi-disciplinary open access archive for the deposit and dissemination of scientific research documents, whether they are published or not. The documents may come from teaching and research institutions in France or abroad, or from public or private research centers.
L'archive ouverte pluridisciplinaire HAL, est destinée au dépôt et à la diffusion de documents scientifiques de niveau recherche, publiés ou non, émanant des établissements d'enseignement et de recherche français ou étrangers, des laboratoires publics ou privés. 


\section{Landslide susceptibility mapping of Cekmece area (Istanbul, Turkey) by conditional probability}

\section{T. Y. Duman ${ }^{1}$, T. Can $^{2}$, C. Gokceoglu ${ }^{3}$, and H. A. Nefeslioglu ${ }^{1}$}

${ }^{1}$ General Directorate of Mineral Research and Exploration, Department of Geological Research, 06520 Ankara, Turkey

${ }^{2}$ Cukurova University, Department of Geological Engineering, 01330 Balcali, Adana, Turkey ${ }^{3}$ Hacettepe University, Department of Geological Engineering, Applied Geology Division, 06532 Beytepe, Ankara, Turkey

Received: 29 November 2004 - Accepted: 17 January 2005 - Published: 19 January 2005 Correspondence to: C. Gokceoglu (cgokce@ hacettepe.edu.tr)

(C) 2005 Author(s). This work is licensed under a Creative Commons License.

\section{Landslide}

susceptibility mapping of Cekmece

T. Y. Duman et al.

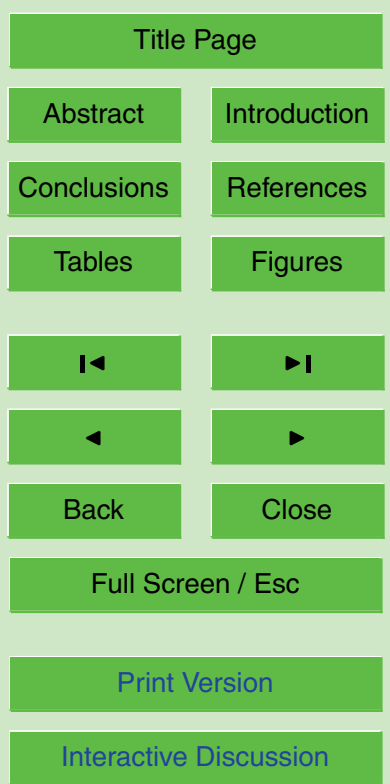

EGU 


\section{Abstract}

As a result of industrialization, throughout the world, the cities have been growing rapidly for the last century. One typical example of these growing cities is Istanbul. Today, the population of Istanbul is over 10 millions. Depending on this rapid urbaniza5 tion, new suitable areas for settlements and engineering structures are necessary. For this reason, the Cekmece area, west of the Istanbul metropolitan area, is selected as the study area, because the landslides are frequent in this area. The purpose of the present study is to produce landslide susceptibility map of the selected area by conditional probability approach. For this purpose, a landslide database was constructed by both air - photography and field studies. $19.2 \%$ of the selected study area is covered by landslides. Mainly, the landslides described in the area are generally located in the lithologies including the permeable sandstone layers and impermeable layers such as claystone, siltstone and mudstone layers. When considering this finding, it is possible to say that one of the main conditioning factors of the landslides in the study area is lithology. In addition to lithology, many landslide conditioning factors are considered during the landslide susceptibility analyses. As a result of the analyses, the class of 5$10^{\circ}$ of slope, the class of 180-225 of aspect, the class of 25-50 of altitude, Danisment formation of the lithological units, the slope units of geomorphology, the class of 800 $1000 \mathrm{~m}$ of distance from faults (DFF), the class of $75-100 \mathrm{~m}$ of distance from drainage (DFD) pattern, the class of $0-10 \mathrm{~m}$ of distance from roads (DFR) and the class of low or impermeable unit of relative permeability map have the higher probability values than the other classes. When compared with the produced landslide susceptibility map, most of the landslides identified in the study area are found to be located in the most (54\%) and moderate (40\%) susceptible zones. This assessment is also supported by susceptibility map produced herein has a valuable tool for the planning purposes.

\section{HESSD}

2, 155-208, 2005

\section{Landslide susceptibility mapping of Cekmece}

T. Y. Duman et al.

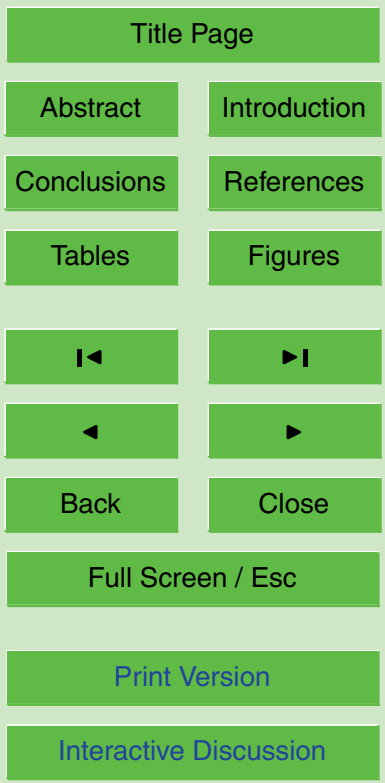

EGU 


\section{Introduction}

In Turkey, landslides are one of the important natural hazards. In the period of 19591994, landslides damaged 76995 buildings throughout Turkey (Ildir, 1995) in addition to death of people, destroyed farming lands and roads etc. For this reason, the regional

5 landslide susceptibility assessments have crucial importance for the landslide - prone areas of Turkey. Within this framework, earth sciences, and geomorphology in particular, may play relevant role in assessing areas at high landslide hazard and in helping to mitigate the associated risk, providing a valuable aid to a sustainable progress. Tools for handling and analysing spatial data (i.e. GIS) may facilitate the application of quan. However, it is possible to find many studies in literature for the landslide susceptibility and hazard mapping. The landslide susceptibility and hazard maps can be produced either by using direct mapping techniques or by using indirect mapping techniques. Direct hazard mapping, in which the degree of hazard is determined by the mapping geomorphologist, based on his experience and knowledge of the terrain conditions (van Westen et al., 1999). Indirect hazard mapping, in which either statistical models or deterministic models are used to predict landslide prone areas, based on information obtained from the interrelation between landscape factors and the landslide distribution (van Westen et al., 1999). In recent years, many studies on the indirect landslide susceptibility mapping have been published depending on the developments of GIS techniques and the digital cartography. It is possible to produce a landslide susceptibility map employing various indirect mapping techniques such as combination of index maps (Gupta and Joshi, 1990; Pachauri and Pant, 1992; Maharaj, 1993; Anbalagan and Singh, 1996; Gokceoglu and Aksoy, 1996; Turrini and Visintainer, 1998; Pachauri

et al., 1998; Wachal and Hudak, 2000; Donati and Turrini, 2002; Ayenew and Barbieri, 2005), statistical analyses (Carrara et al., 1991; Jade and Sarkar, 1993; Atkinson and Massari, 1998; Fernandez et a., 1999; Guzzetti et al., 1999; Baeza and Corominas, 2001; Lee and Min, 2001; Pistocchi et al., 2002; Ercanoglu et al., 2004; Suzen and

\section{HESSD}

2, 155-208, 2005

\section{Landslide susceptibility mapping of Cekmece}

T. Y. Duman et al.

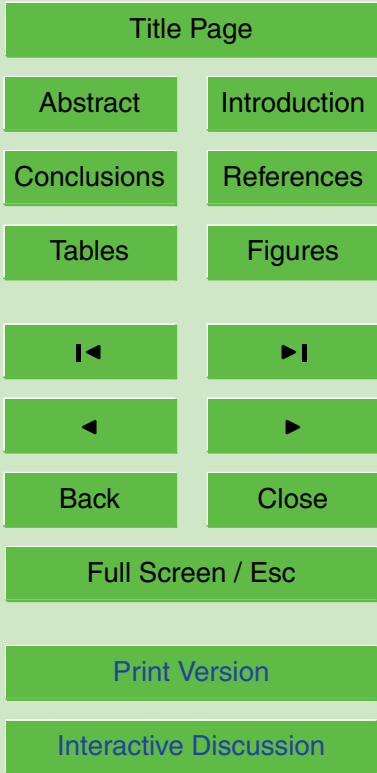

EGU 
Doyuran, 2004a; Ayalew and Yamagishi, 2004), probabilistic approach (Gritzner et al., 2001; Rowbotham and Dudycha, 1998; Clerici et al., 2002), neural networks (Lee et al., 2001, 2003 and 2004; Gomez and Kavzoglu, 2004) and fuzzy approach (Juang et al., 1992; Binaghi et al., 1998; Ercanoglu and Gokceoglu, 2002 and 2004). It is 5 evident that each landslide susceptibility assessment method considered by landslide community has some advantages and drawbacks. For this reason, among the landslide researchers, there is no agreement either on the methods or on the scope of producing hazard maps (Brabb, 1984). Surprisingly, Brabb's idea (Brabb, 1984) is still valid for the techniques employed in landslide susceptibility mapping studies, because 10 regional landslide susceptibility assessments pose complex problems due to a lack of knowledge and variability.

A hundred years ago, the world population totalled 1.1 billion, and about $5 \%$ of people lived in cities. Today, the population has risen to 5.3 billion and approximately $45 \%$ of it is concentrated in urban areas. The most explosive growth has been in the de15 veloping world, where urban populations have tripled in the last 30 years. Between the years of 1950-1995, the number of cities with population of more than one million increased sixfold in the third world (Helmore, 1996; after Guzzetti et al., 1999). One typical example among the cities having explosive growth is Istanbul. This metropolitan city, located in the northern west of Turkey, is the most crowded city of Turkey with a population of above 10 million and Istanbul is also the financial and cultural centre of Turkey. At the same time, it is a city world-famous for its natural beauty and historical monuments, reflecting its role as the capital of three separate empires. It enjoys the unique amenities of shorelines on the Black Sea, the Marmara Sea and the Bosphorus Strait. The rapid growth of the city since the 1950s, due to rural migration, has affected the quality of life in various sections of the city (Dokmeci and Berkoz, 2000). Due to this rapid growth of Istanbul, new settlement areas are needed and the study area is one of the new settlemet areas of Istanbul. In the study area (Fig. 1), new tall appartments, houses having two or three storeys and factories are constructed. Moreover, as a result of urbanization, new roads, highways and lifelines are built up.

HESSD

2, 155-208, 2005

\section{Landslide susceptibility mapping of Cekmece}

T. Y. Duman et al.

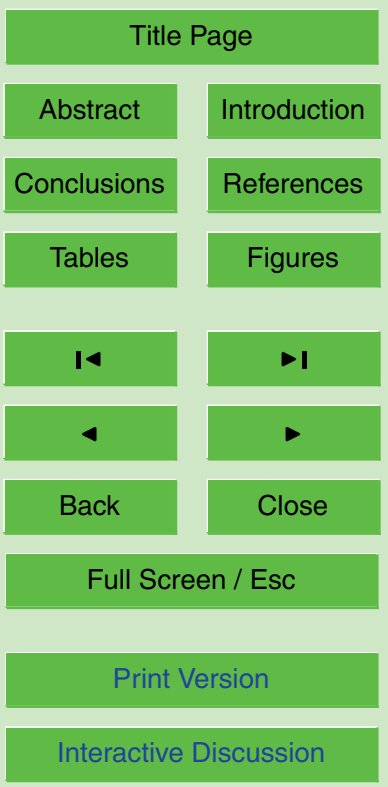

EGU 
As can be seen in Fig. 2, many structures in the study area are constructed in active landslides and/or the areas susceptible to landsliding. For this reason, preparation of a realistic landslide susceptibility map for the planning and correct site selection purposes is indispensable. Generally, the landslide susceptibility maps help to planners 5 and decision - makers for correct site selection and planning. For this reason, in this study, production of landslide susceptibility map of a part of Istanbul, Cekmece area is aimed considering conditional probability method. This study is composed of four main stages such as (a) preparation of landslide inventory by air - photography studies, (b) field checks of landslide inventory, (c) preparation of index maps of the study area and production of landslide susceptibility map, and (d) assessment of performance of the produced landslide susceptiblity map.

\section{General properties of the study area}

The study area locates at the northern coast of the sea of Marmara and western part of Istanbul metropolitan area (see Fig. 1). The Buyuk Cekmece lake, and the Kucuk 15 Cekmece lake and Dikilitas creek are the western and eastern borders of the study area, respectively. The study area is in the Marmara region having a high - seismicity. Recently, Turkey has experienced some large earthquakes. The 17 August 1999 Izmit earthquake on the NAF's northern branch has also increased the earthquake risk in the Sea of Marmara (Parsons et al., 2000). More than 300 earthquakes are reported to have occurred between 2100 BC and AD 1900 (Soysal et al., 1981). The active northern branch of the Northern Anatolian Fault Zone (NAFZ) passes through the distance of $9 \mathrm{~km}$ from south of the study area. In the last 20 centuries, between Izmit and Gulf of Saros, 29 historically large (between 6.3 and $7.4 M_{s}$ ) earthquakes occurred along the northern branch NAFZ (Ambraseys, 2002). One of the main landslide triggers is earthquakes while the other is heavy rainfall. The seismicity of the study area becomes one of these triggers.

In the stratigraphic succession, the Kirklareli limestone, the oldest rocks of the study

\section{Landslide susceptibility mapping of Cekmece}

T. Y. Duman et al.

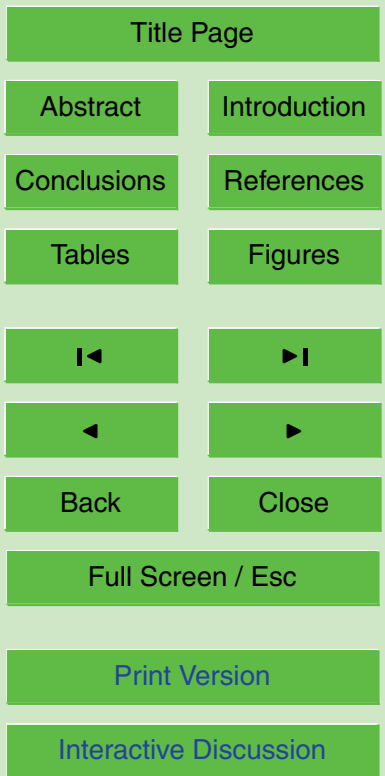

EGU 
area of the Middle-Late Eocene, observed in the eastern parts of the study area. The Insaniye formation, interfingered with the Kirklareli limestone, consists of sedimentary units such as shale-marls of the Late Eocene-Early Oligocene observed in the northern parts of the study area (Fig. 3). The Danisment formation of Late Oligocene includes 5 alternance of sandstone, shale and marl with thin-moderate beddings (Fig. 4) (Duman et al., 2004). This formation is observed at the western parts of the study area. Sandstone and shale alternation bearing gypsum and coal layers comprising the Suloglu formation is interfingered with the Danisment formation. Tuffs, sandstones and gravelstones form the Cantakoy formation, appear in the southwestern and southern parts of 10 the area. The age of the Cantakoy formation is Early Miocene. The Ergene formation unconformably lie over the Cantakoy formation. The age of the Ergene formation is Middle Miocene and it consists of sandstones and gravelly sandstones. This formation is observed at northern and southern parts of the area. The Bakirkoy formation, represented by limestones and claystones, crops out middle parts of the area (Fig. 3). The age of the Bakirkoy formation is Late Miocene (Safak et al., 1999). The terraces unconformably covers the oldest rocks and it is observed at the coast of Buyuk Cekmece lake. The youngest unit in the study area is actual alluviums.

In the area, some inactive normal faults are typical. The direction of these faults are generally northeast - southwest, but that of the most important normal fault, Yesilbayir fault, is roughly northwest - southeast (Duman et al., 2004). These faults can be observed in the Miocene lithologies in the area. The dip values of the beddings of the sedimentary units in the area are rather low, 5-15. For this reason, the strikes and the dip directions exhibit a high variation in short distances. However, in the study area, there is no considerable folding.

25 The altitude values vary between $0-200 \mathrm{~m}$ while the dominant altitude ranges are 75-100 and 100-125 m (Figs. 5a and 5b). The study area has a dendritic drainage pattern, because of presence of soft lithologies and low slope angles. The general physiographic trend of the study area is NW-SE as can be seen in Figs. 6a and 6b. Although the range of slope angle values is 0 to $90^{\circ}$, the majority of them are between

HESSD

2, 155-208, 2005

\section{Landslide susceptibility mapping of Cekmece}

T. Y. Duman et al.

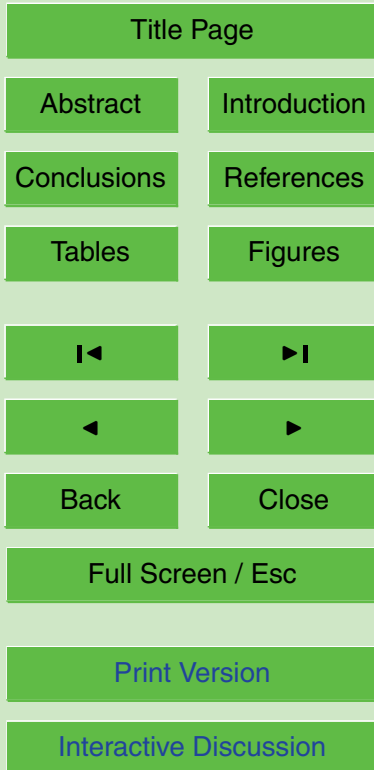

EGU 
$0-20^{\circ}$ (Figs. $7 \mathrm{a}$ and $7 \mathrm{~b}$ ). These slope values indicate that the majority of the area has gentle slopes.

The geomorphology map of the study area was produced by Duman et al. (2004) (Fig. 8). In the study area, denudation and pediment surfaces, slope zones, transition 5 zones, alluvial floors and coastal zones form the main geomorphological units. Considering the purpose of the present study, the most important geomorphological units are the slope zones contributing the landslides occurrence. Especially, lower borders of the Late Miocene eroding surfaces are the failure surfaces of the landslides in the region (Duman et al., 2004). In addition, a dense landslide occurrence can be observed at 10 the slope zones near the coast lines of the lakes and the Sea of Marmara in the area.

According to the relative permeability map of the lithologies prepared by Duman et al. (2004), considering the classification of proposed by Todd (1980), permeable, semi - permeable and impermeable units exist in the area (Fig. 9). Mainly, the eastern and southern parts of the area have permeable units while impermeable and semi 15 permeable units are dominant at the western and northern parts of the area. In the area, there are many springs. These springs discharge along the borders of permeable and semi or impermeable units. This indicates that the permeable units have a considerable groundwater. The main streams in the study area are the Dikilitas creek, Cekmece creek, Uzuncayir creek and Harami creek. The general stream direction of the Cekmece creek and Uzuncayir creek in the study area is from northeast to southwest and they discharge to the Cekmece lake while that of Dikilitas creek is northwest to southeast and it discharges to the Sea of Marmara. Besides, there are many lower order streams flowing only after rainy periods and their flowing directions are generally southwest.

25 In the region, the Marmara and Western Black Sea climate prevails. Generally, in the summer season, the weather is hot and slightly rainy while the weather of winter seasons is warm and rainy. The topography of the region and presence of lakes and dams affect the weather conditions (http://istanbul.meteor.gov.tr). The region receives $85 \%$ of the total annual precipitation in rainy season, September-May (http://istanbul.

HESSD

2, 155-208, 2005

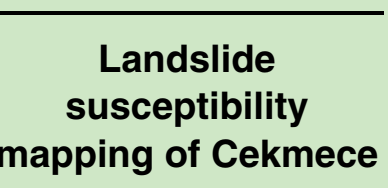

T. Y. Duman et al.

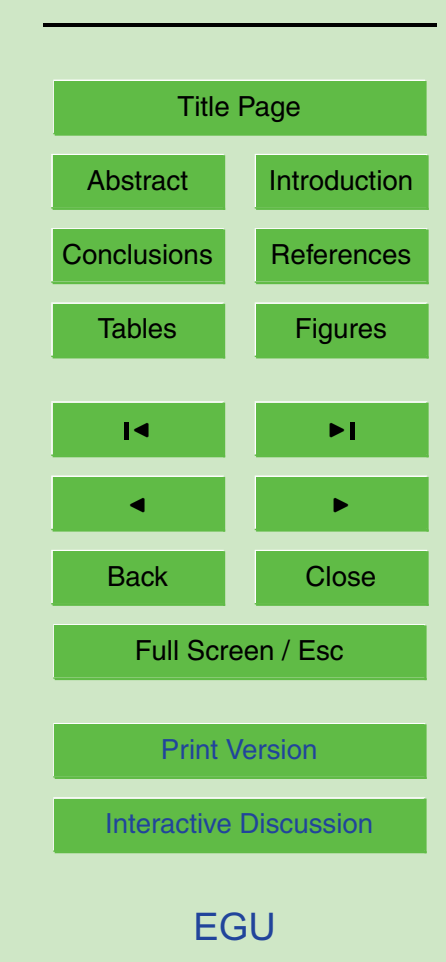


meteor.gov.tr). In this study, the data of Florya Meteorology Station, the nearest station to the study area, was employed. According to the meteorological data of the period of 1937-1990, the average monthly rainfall varies between $20.5 \mathrm{~mm}$ and $102.0 \mathrm{~mm}$ (Fig. 10). The annual precipitation varies between $500 \mathrm{~mm}$ and $1000 \mathrm{~mm}$ in the region 5 while average annual precipitation of long period of the Florya Meteorology Station is $642.4 \mathrm{~mm}$ (DMI, 1990). The average monthly temperature varies from $5.3^{\circ} \mathrm{C}$ to $23.2^{\circ} \mathrm{C}$. The coldest month is January with average temperature of $5.3^{\circ} \mathrm{C}$ and the hottest month is July with average temperature of $23.2^{\circ} \mathrm{C}$. In winter seasons particularly, the region sometimes receive heavy precipitation causing some floods and triggering landslides.

10 The maximum daily precipitation recorded in the period of 1937-1990 varies between $43.8 \mathrm{~mm}$ and $112.5 \mathrm{~mm}$ (DMI, 1990). When $112.5 \mathrm{~mm}$ is considered, the maximum rainfall intensity is calculated as $4.7 \mathrm{~mm} / \mathrm{h}$. As a consequence, the region has the landslide triggers such as earthquake and heavy precipitation. However, in this study, the conditioning factors are only taken into consideration when producing landslide 15 susceptibility map.

\section{Landslide characteristics}

In the hope that the geomorphologic conditions of a specific dynamic type of mass movement (e.g. shallow translational landslides, debris flows, rock falls) can be sufficiently described by corresponding combinations of basic thematic maps (e.g. to20 pographic slope, land cover, lithological units, distribution of past landslides) spatial databases need to be constructed for analysing and modelling by geographical information systems (GIS) (Fabbri et al., 2003). In general, mapping past and recent slope movements, together with the identification and mapping of the conditioning or preparatory factors of slope instability, are the keys in predicting future landslides (Carrara et 25 al., 1998). A reliable landslide inventory defining the type and activity of all landslides, as well as their spatial distribution, is essential before any analysis of the occurrence of landslides and their relationship to environmental conditions undertaken (Soeters

HESSD

2, 155-208, 2005
Landslide susceptibility mapping of Cekmece

T. Y. Duman et al.

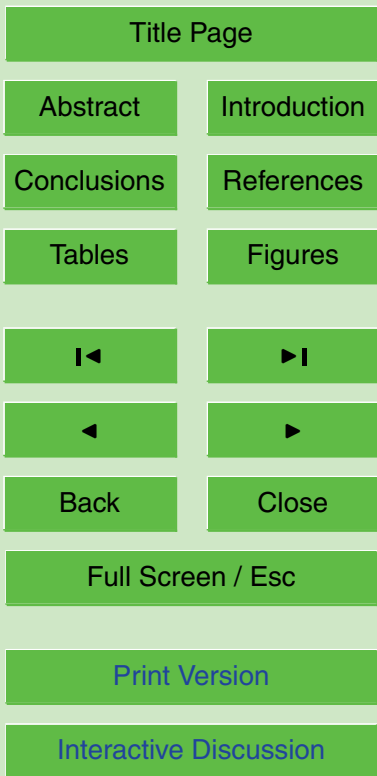

EGU 
and van Westen, 1996). Therefore, it is possible to say that a reliable landslide inventory is a crucial part of a landslide susceptibility map among the parameters employed, because it is the fundamental component of the assessments.

In Turkey, there are no a landslide inventory at the national scale. For this reason, 5 in this study, a landslide inventory was prepared by using the vertical black-and-white aerial photographs of medium scale (1:35000), dated 1955-1956, were used to identify the landslides. When describing the type and activity of the landslides in the study area, the similar criteria defined in the Turkish Landslide Inventory Mapping Project initiated by the Natural Hazards and Environmental Geology division of the General Di10 rectorate of Mineral Research and Exploration (MTA) were considered. In this project (Duman et al., 2001), mass movements were classified according to the main types of classification proposed by Varnes (1978), i.e. flows, falls and slides. The landslides are also classified according to their relative depths, as shallow - (depth $<5 \mathrm{~m}$ ) and deepseated (depth $>5 \mathrm{~m}$ ). For simplicity, their activities are classified into two groups as 15 active and inactive. Active landslides are defined as those currently moving, whereas inactive ones are as relict according to WP/WLI (1993). Shallow landslides are classified as active because of their ongoing observed movements (Duman et al., 2005). The landslide locations described in the air-photography studies were controlled by field studies. One of the most important stages of landslide susceptibility mapping is 20 to describe the factors governing the landslides identified in the area. To complete this stage, an extensive field study is needed to describe the mechanisms, activity and conditioning factors of landslides. For this purpose, in this study, following the air-photography studies, a field study was conducted. During the field studies, some observations were carried out on the areal extent of landslides and their mechanisms. 25 The characters of landslides identified in the area are mainly deep seated and active.

The landslides are the most frequent in the selected study area when compared with the Trakya region. The described landslides are generally located in the lithologies including the permeable sandstone layers and impermeable layers such as claystone, siltstone and mudstone layers. This is typical for the landslides identified in the study

HESSD

2, 155-208, 2005

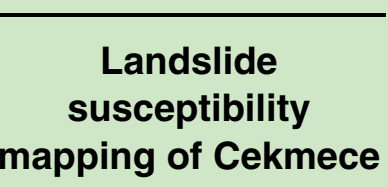

T. Y. Duman et al.

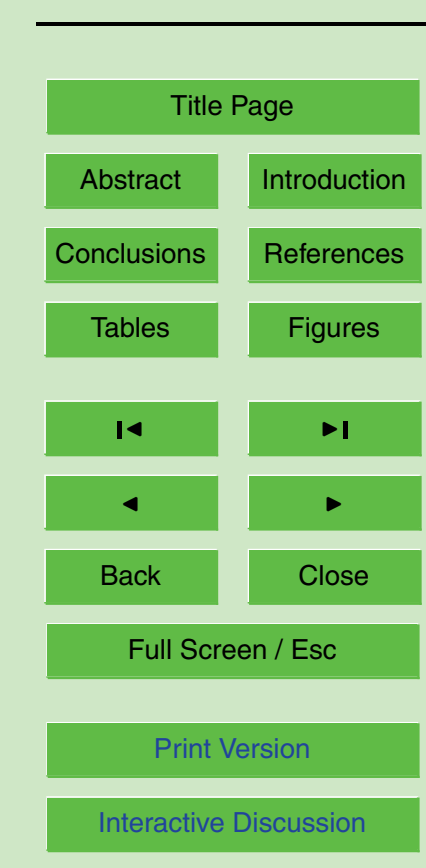

EGU 
area. When considering this finding, it is possible to say that one of the main conditioning factors of the landslides in the study area is lithology. This can be seen clearly in Fig. 11. As can be seen in Fig. 11, the majority of the landslides (approximately $60 \%$ ) occurred in two formations such as Danisment formation - Acmalar member 5 (Toda) and Ergene (Tme) formations. An another factor governing the landslides is the sandstone bedding planes and their orientations. If there is a daylight between the orientation of slope and bedding plane, some large landslides occur (Fig. 12). In these areas, the beginning of the landslides are controlled by the bedding planes as planar failure, and then in the displaced and accumulated material, some rotational landslides 10 are observed (Fig. 13). Rarely, in this material, some earthflows may occur depending on the heavy rainfalls. The average failure surface depth of the landslides described in the study area is about $15 \mathrm{~m}$ (Arpat, 1999). Based on cross-sections, however, the estimated maximum failure are about 20-25 $\mathrm{m}$. The pixel number of the landslide areas is 53674 , this indicates that $19.2 \%$ of the study area is covered by the landslides.

15 The most important topographical factor conditioning landslides is the slope angle. In the regional landslide susceptibility or hazard assessments, several researchers (Roth, 1983; Barisone and Bottino, 1990; Koukis and Ziourkas, 1991; Anbalagan, 1992; Pachauri and Pant, 1992; Maharaj, 1993; Jager and Wieczorek, 1994; Anbalagan and Singh, 1996; Atkinson and Massari, 1998; Baum et al., 1998; Guzzetti et al., 1999;

20 Zezere et al., 1999; Guzzetti et al., 2000; Jakob, 2000; Nagarajan et al., 2000) took into consideration statistical techniques for the assessment of slope angle in terms of landslide activity. In the study area, the frequency of the identified landslides reached peak value at the slope angle range of $5-15^{\circ}$ (Fig. 14) and the slope angle is considered as a conditioning factor during the analyses.

$25 \quad$ Although the relation between slope aspect and mass movement has long been investigated, no general agreement exists on slope aspect (Carrara et al., 1991). Several authors (i.e. Carrara et al., 1991; Maharaj, 1993; Gokceoglu and Aksoy, 1996; Jakob, 2000; Nagarajan et al., 2000) considered the slope aspect as a factor conditioning the landslides. Mainly, the slope aspect is related to the general physiographic trend of the

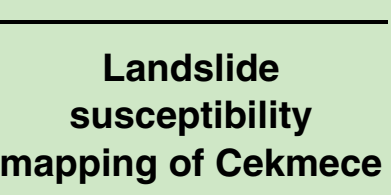

T. Y. Duman et al.

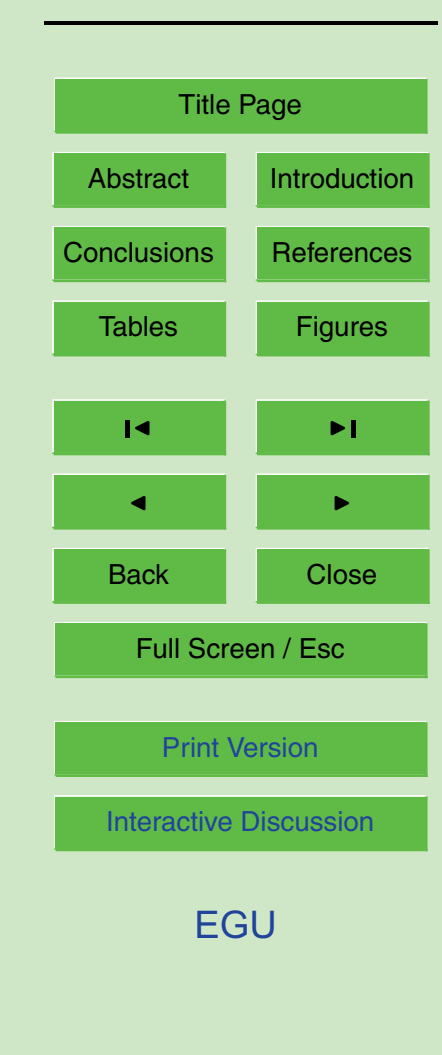


area and/or the main precipitation direction. The relationship between direction of the landslides and general physiographic trend of the area should be roughly perpendicular. The general physiographic trend of the area is NW-SE and an important part of the HESSD landslides observed in the area studied has failure directions to NE and NW (Fig. 15).

$5 \quad$ Some authors (i.e. Pachauri and Pant, 1992; Ercanoglu and Gokceoglu, 2002) reported that the altitude is a good indicator for the landslide susceptibility assessments. However, in the area studied, there is no a considerable difference between the lowest and the highest altitude values, $200 \mathrm{~m}$. For this reason, there is no an agreement between landslide frequency and altitude (Fig. 16). Even though this finding, the altitude 10 is taken into consideration in the analyses.

It can be thought as the structural elements such as faults, folds, joints or some parts of them, make the materials where landslides occur more susceptible to sliding because of material weakening, stress accumulation or tectonic activity in different distances. However, there is not a consensus among the researchers about the dis15 tances from the structural elements to be considered. As a result, the researchers have used different distances with respect to the closeness to the structural elements in the literature (Anbalagan, 1992; Pachauri and Pant, 1992; Maharaj, 1993; Gokceoglu and Aksoy, 1996; Luzi and Pergalani, 1999; Donati and Turrini, 2002; Ercanoglu and Gokceoglu, 2004). In this study, inactive faults in the study area are considered as the structural elements and the distances of $0-200,200-400,400-600,600-800,800-$ 1000 , and $>1000 \mathrm{~m}$ to the faults are buffered (Fig. 17) and the landslide distribution in these buffer zones is shown in Fig. 18. It is evident that the majority of the landslides locates in the zone of $>1000 \mathrm{~m}$. However, the class of $>1000 \mathrm{~m}$ is accepted as the zone unaffected from the faults. For this reason, during the analyses, the probability of 25 this class is accepted as zero.

One of the important factors conditioning the landslides is the proximity to the drainage pattern, because streams may adversely affect the stability by either eroding the toe or saturating the slope material or both (Gokceoglu and Aksoy, 1996). For this reason, this parameter is also evaluated by creating buffer zones of $0-25,25-50$,

2, 155-208, 2005

\section{Landslide susceptibility mapping of Cekmece}

T. Y. Duman et al.

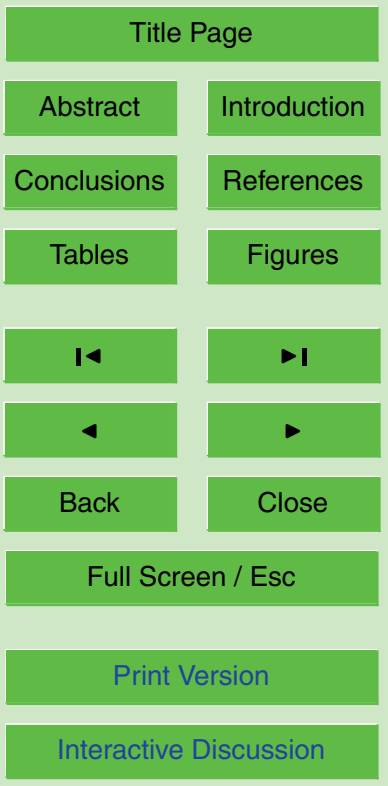

EGU 
50-75, 75-100, 100-125, and >125 m (Fig. 19), and the results is given in Fig. 20. However, there is no an agreement between the landslide density and the proximity to drainage pattern. $85.3 \%$ of the landslides accumulate in the class of $>125 \mathrm{~m}$. However, this class is not considered during the analyses.

5 In addition to the lithological features, the relative permeability map of the units is taken into consideration as the conditioning factors of the landslides. One of the main conditioning factors is permeability characteristic of the units (Fig. 21). $88.6 \%$ of the landslides is in the class of $>50 \mathrm{~m}$ of the distance from roads (Fig. 22 and Fig. 23). This is typical for all the parameters having the line character such as roads, faults and

10 drainage pattern. Due to the fact that this line character, the class of $>50 \mathrm{~m}$ is not taken into consideration during the analyses. The geomorphological units and land - units are considered in the landslide susceptibility analyses (Fig. 24). As an expected result, most of the landslides locate in the slopes while minority of them is observed in the landslide morphology (PH) and Upper Miocene infilling surfaces (UMDY).

\section{Methodology}

In the present study, the digital elevation model (DEM) was produced by digitizing $10 \mathrm{~m}$ altitude contours of the 1/25000 scaled topographical maps. The slope, aspect and altitude maps obtained from the DEM are raster maps with a pixel size of $25 \times 25 \mathrm{~m}$. However, the other maps such as lithology, geomorphology, distance from faults, dis20 tance from drainage, distance from roads, relative permeability and landslide inventory are vector maps, and these maps were converted to raster maps with a pixel size of $25 \times 25 \mathrm{~m}$ for the implementation in the susceptibility analyses.

Landslide susceptibility evaluation involves a high level of uncertainty due to data limitations and model shortcomings (Zezere, 2002). For this reason, the landslide researchers have considered different techniques for preparation landslide susceptibility maps as mentioned in the introduction chapter of this paper. One of these techniques is statistical analyses. Among the statistical techniques, a special place is held by Con-

\section{Landslide susceptibility mapping of Cekmece}

T. Y. Duman et al.

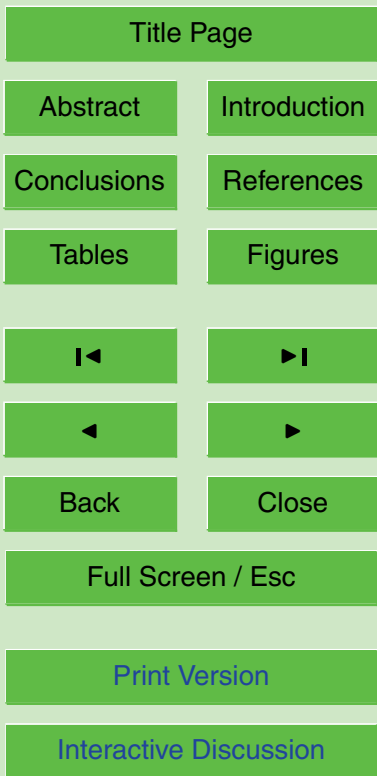

EGU 
ditional Analysis, a conceptually simple technique which is highly compatible with GIS operating features and produces results that can easily be assessed by non-specialists (Clerici et al., 2002). This method is profitably applied in relation to a particular land surface subdivision in the so-called Unique Condition Units (Carrara et al., 1995), Unique 5 Condition Subareas (Chung et al., 1995) or pixels. Mainly the probability that event A will occur if event B occurs is called the conditional probability (Negnevitsky, 2002). More specifically, the conditional probability approach considers a number of factors governing the landslides, which are thought to be strictly connected with landslide occurrence. The data layers, in which each factor is subdivided into a convenient number 10 of classes, are crossed in order to obtain all the possible combinations of the various classes of the different factors (Clerici et al., 2002). Each specific combination represents a pixel. Subsequently, the landslide spatial frequency, usually represented by the landslide density, is determined within each pixel. Assuming the already mentioned principle that slope-failure in the future will be more likely to occur under those conditions which led to past instability and working on the statistical concept whereby the frequency of an event, the density of an event, equals the probability that the same event will occur, the resulting landslide density equals the landslide susceptibility (Clerici et al., 2002). Conditional probability is denoted mathematically as $p$ (AIB) (Eq. 1) (Negnevitsky, 2002).

$20 \mathrm{P}(\mathrm{A} \mid \mathrm{B})=$ (the number of times $\mathrm{A}$ and $\mathrm{B}$ can occur)/(the number of times $\mathrm{B}$ can occur).

The number of times $A$ and $B$ can occur, or the probability that both $A$ and $B$ will occur, is also called "joint probability" of $A$ and $B$. It represents mathematically as $P(A \cap B)$. The number of ways $B$ can occur is the probability of $B, P(B)$;

$P(A \mid B)=P(A \cap B) / P(B)$.

25 Similarly, the conditional probability of event B occurring given that event A has occurred equals;

$P(B \mid A)=P(B \cap A) / P(A)$.

HESSD

2, 155-208, 2005

\section{Landslide susceptibility mapping of Cekmece}

T. Y. Duman et al.

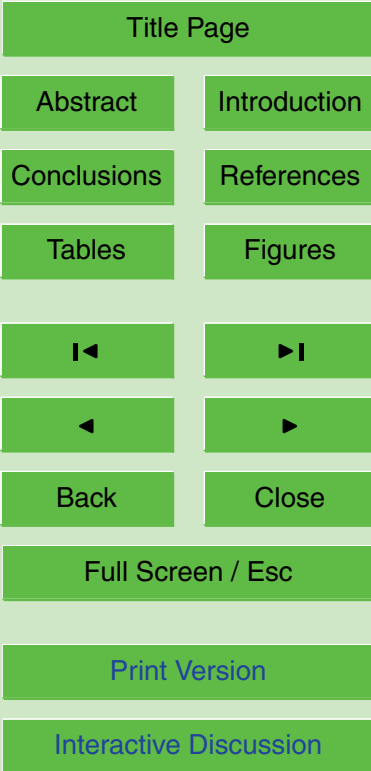

EGU 
Hence,

HESSD

$P(B \cap A)=P(B \mid A) \times P(A)$.

2, 155-208, 2005

The joint probability is commutative, thus;

$P(A \cap B)=P(B \cap A)$,

5 therefore,

$P(A \mid B)=[P(B \mid A) \times P(A)] / P(B)$.

\section{Landslide \\ susceptibility mapping of Cekmece}

The last equation (Eq. 6) is known as the Bayesian rule. This principle can extended to event $A$ being dependent on a number of mutually exclusive events $B_{1}, B_{2}, \ldots, B_{n}$. The following set of equations can then be derived from Eq. (2):

$P\left(A \cap B_{1}\right)=P\left(A \mid B_{1}\right) \times P\left(B_{1}\right)$

$\mathrm{P}\left(\mathrm{A} \cap \mathrm{B}_{2}\right)=\mathrm{P}\left(\mathrm{A} \mid \mathrm{B}_{2}\right) \times \mathrm{P}\left(\mathrm{B}_{2}\right)$

T. Y. Duman et al.

:

$\mathrm{P}\left(\mathrm{A} \cap \mathrm{B}_{n}\right)=\mathrm{P}\left(\mathrm{A} \mid \mathrm{B}_{n}\right) \times \mathrm{P}\left(\mathrm{B}_{n}\right)$

15 or, when combined;

$\mathrm{P}(\mathrm{A})=\sum_{i=1}^{n} \mathrm{P}(\mathrm{A} \cap \mathrm{B})=\sum_{i=1}^{n} \mathrm{P}\left(\mathrm{AlB}_{i}\right) \times \mathrm{P}\left(\mathrm{B}_{i}\right)$.

In the present study, Eq. (7) was employed to obtain the final susceptibility map the area.

The limitations of this approach are summarized by Clerici et al. (2002). According 20 to these researchers (Clerici et al., 2002), one such limitation is the necessity to introduce a limited number of factors subdivided into a limited number of classes into

\section{Title Page}

Abstract

Introduction

Conclusions

References

Tables

Figures

14

4

Back

Close
Full Screen / Esc

Print Version

Interactive Discussion 
the analysis. Otherwise, a high number of pixels of small dimensions, and so of little statistical significance, could result from the crossing of the data layers. But probably the most limiting aspect is that an eventual change of the factors, or simply their reclassification, implies restarting the entire procedure which, however conceptually simple it 5 may be, is nevertheless complicated to execute. To overcome this difficulty, Clerici et al. (2002) have produced a shell program (or shell script) that executes the procedure automatically making it, therefore, possible to repeat it quickly and with limited user involvement.

In recent years, the conditional probability approach has been applied successfully 10 to produce landslide susceptibility maps by researchers (Clerici et al., 2002; Suzen and Doyuran, 2004a; Lee, 2004). According to the findings of Suzen and Doyuran (2004b) and Lee (2004), the logical regression analysis seems to be more consistent when compared with the conditional probability. However, the application of conditional probability to the production of landslide susceptibility maps is easy; the process of input, 15 calculation, and output can be readily understood. Also, the speed of bivariate methods could be said to be an advantage over multivariate methods (Suzen and Doyuran, 2004b). For these reasons, the conditional probability approach is preferred to prepare the landslide susceptibility map of Cekmece area.

In the first stage of the application of the conditional probability approach, the $p(\mathrm{~A} \mid \mathrm{B})$, $20 \quad p(\mathrm{~A})$ and $p(\mathrm{~B})$ values are calculated (Table 1). Then, the probability values for landslide susceptibility are calculated for each pixel by summing up the $p(\mathrm{~A})$ values of each conditioning parameter considered in this study. Considering the probability values, the final landslide susceptibility map of the Cekmece area is produced (Fig. 25). Also, to assess the weights of the parameters visually, the weights of each parameter class 25 are calculated (Eq. 8) and given in Fig. 26.

$w=\mathrm{P}(\mathrm{A} \mid \mathrm{B})-($ area of all landslides $) /($ whole area $)$.

As can be seen in Fig. 26, some classes of the lithology, slope, aspect, altitude, geomorphology, distance from drainage and relative permeability are the most effective parameters on the landslides identified in the study area (Fig. 26).

HESSD

2, 155-208, 2005

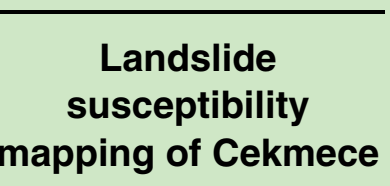

T. Y. Duman et al.

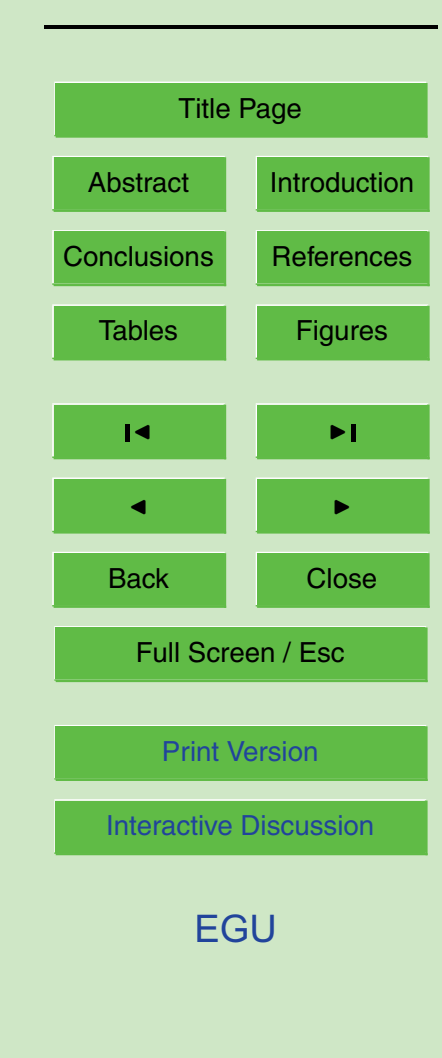


When making a close inspection to the produced susceptibility map, it can be observed that a considerable part of the slopes having NW-SE direction have the most susceptible zones to landsliding (Fig. 25). When compared with the produced landslide susceptibility map for the Cekmece area, all of the landslides identified in the study area 5 are found to be located in the most (54\%) and moderate (40\%) susceptibility classes. As far as performance of the conditional probability approach for processing is concerned (Fig. 27), the images appear to be quite satisfactory, the zones described on the map being zones of relative susceptibility. The approach employed herein can be taken into consideration to be practical for assessing the susceptibility to landsliding.

10 The produced landslide susceptibility map will help to the decision makers during site selection and site planning processes. This map may also be accepted as a basis for the landslide risk management studies to be applied in the study area.

\section{Results and conclusions}

The following results and conclusions can be drawn from the present study.

15 The sedimentary units having different ages form the lithology of the study area are shale - marls of the Late Eocene - Early Oligocene, alternance of sandstone, shale and marl of Late Oligocene, tuffs, sandstones and gravelstones of Early Miocene, sandstones and gravely sandstones of Middle Miocene, limestones and claystones of Late Miocene, the terraces and actual alluviums. The dip values of the beddings of these sedimentary units are rather low. For this reason, the strikes and the dip directions exhibit a high variation in short distances. However, in the study area, there is no considerable folding while some inactive normal faults are typical. The direction of these faults are generally NE-SW.

The study area has a dendritic drainage pattern, because of presence of soft litholo25 gies and low slope angles, and the general physiographic trend of the study area is NW-SE. The majority of the area has gentle slopes.

$19.2 \%$ of the study area is covered by the landslides. The described landslides

\section{Landslide susceptibility mapping of Cekmece}

T. Y. Duman et al.

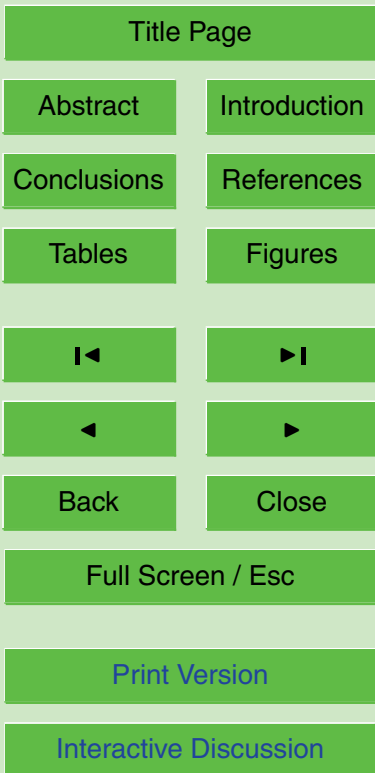

EGU 
are typically located in the lithologies including the permeable sandstone layers and impermeable layers such as claystone, siltstone and mudstone layers. Considering this finding, it is possible to say that one of the main conditioning factors of the landslides in the study area is lithology. An another factor governing the landslides is the sandstone 5 bedding planes and their orientations. If there is a daylight between the orientation of slope and bedding plane, some large landslides occur. In these areas, the beginning of the landslides are controlled by the bedding planes as planar failure, and then in the displaced and accumulated material, some rotational landslides are observed. Rarely, in this material, some earthflows may occur depending on the heavy rainfalls.

10 Altitude, slope, aspect, lithology, distance to faults, distance to drainage, distance to roads, geomorphological units and relative permeability map are considered as the conditioning factors of the landslides. The results of conditional probability analyses revealed that the classes of $5-10^{\circ}$ of slope, the class of 180-225 of aspect, the class of 25-50 of altitude, Danisment formation - Acmalar member (Toda) of the lithological 15 units, the slope units of geomorphology, the class of $800-1000 \mathrm{~m}$ of distance to faults, the class of $75-100 \mathrm{~m}$ of distance to drainage pattern, the class of $0-10 \mathrm{~m}$ of distance to roads and the class of low or impermeable unit of relative permeability map have the higher probability values than the other classes.

When compared with the so - prepared landslide susceptibility map, all of the landslides identified in the study area are found to be located in the most (54\%) and moderate $(40 \%)$ susceptible zones. This assessment is also supported by the performance analysis. As a consequence, the produced landslide susceptibility map can be accepted as valuable performance for the planning purposes.

The produced landslide susceptibility map will help to the decision makers during 25 site selection and site planning processes. This map may also be accepted as a basis for the landslide risk management studies.

HESSD

2, 155-208, 2005

\section{Landslide susceptibility mapping of Cekmece}

T. Y. Duman et al.

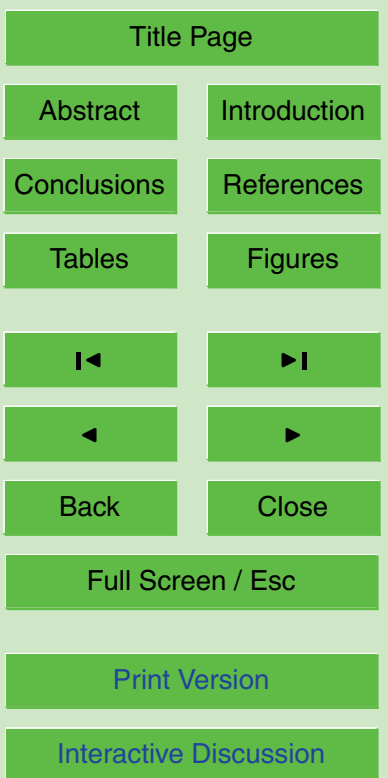

EGU 


\section{References}

Ambraseys, N.: The seismic activity of the Marmara Sea region over the last 2000 years, B Seismol. Soc. Am., 92, 1, 1-18, 2002.

Anbalagan, R.: Landslide hazard evaluation and zonation mapping in mountainous terrain, Engineering Geology 32, 269-277, 1992.

Anbalagan, R. and Singh, B.: Landslide hazard and risk assessment mapping of mountainous terrains - a case study from Kumaun Himalaya, India, Engineering Geology, 43, 237-246, 1996.

Arpat, E.: Büyükcekmece ile Kucukcekmece (Istanbul) heyelanlarinin genel ozellikleri ve yarattiklari baslica sorunlar, In: Proceedings of the 52, Turkey Geological Congress, 17-23, 1999 (In Turkish).

Atkinson, P. M. and Massari, R.: Generalised linear modelling of susceptibility to landsliding in the Central Appenines, Italy, Computers and Geosciences, 24, 4, 373-385, 1998.

Ayalew, L. and Yamagishi, H.: The application of GIS-based logistic regression for landslide susceptibility mapping in the Kakuda-Yahiko Mountains, Central Japan, Geomorphology, doi:10.1016/j.geomorph.2004.06.010, in press, 2004.

Ayenew, T. and Barbieri, G.: Inventory of landslides and susceptibility mapping in the Dessie area, northern Ethiopia, Engineering Geology, in press, 2004.

Baeza, C. and Corominas, J.: Assessment of shallow landslide susceptibility by means of multivariate statistical techniques, Earth Surface Processes and Landforms, 26, 1251-1263, 2001.

Binaghi, E., Luzi, L., Madella, P., Pergalani, F., and Rampini, A.: Slope instability zonation: a comparison between certainty factor and fuzzy Dempster - Shafer approaches, Natural Hazards, 17, 77-97, 1998.

Barisone, G. and Bottino, G.: A practical approach for hazard evaluation of rock slopes in mountainous areas, Proceedings of the 6th Int. IAEG Cong., Balkema, 1509-1515, 1990.

Baum, R. L., Chleborad, A. F., and Schuster, R. L.: Landslides triggered by the winter 19961997 stroms in the Puget Lowland, Washington, U.S. Geological Survey, Open-File Report 98-239, 1998.

30 Brabb, E. E.: Innovative approaches to landslide hazard and risk mapping, In: Proceedings of 4th International Symposium on Landslides, September 1984, Toronto, Canada, 1, 307-323, 1984.

\section{HESSD}

2, 155-208, 2005

\section{Landslide susceptibility mapping of Cekmece}

T. Y. Duman et al.

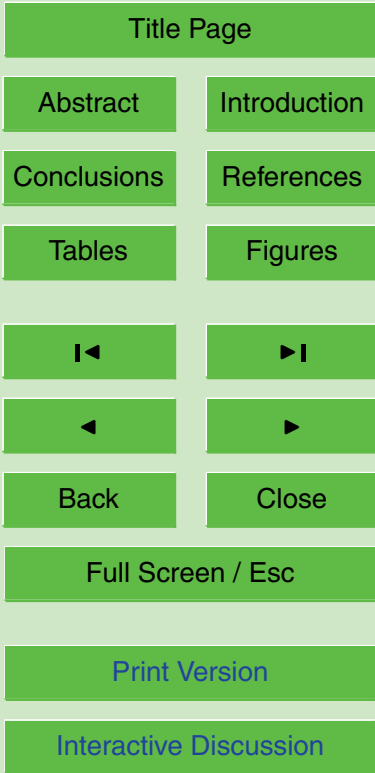

EGU 
Carrara, A., Cardinali, M., Detti, R., Guzzetti, F., Pasqui, V., and Reichenbach, P.: GIS techniques and statistical models in evaluating landslide hazard, Earth Surface Processes and Landforms, 16, 5, 427-445, 1991.

Carrara, A., Cardinali, M., Guzzetti, F., Reichenbach, P.: GIS based techniques for mapping landslide hazard, (http://deis158.deis.unibo.it), 1995.

Carrara, A., Guzzetti, F., Cardinali, M., and Reichenbach, P.: Current limitations in modeling landslide hazard, In Proceedings of IAMG'98, edited by Buccianti, A., Nardi, G., and Potenza, R., 195-203, 1998.

Clerici, A., Perego, S., Tellini, C., and Vescovi, P.: A procedure for landslide susceptibility zonation by the conditional analysis method, Geomorphology, 48, 349-364, 2002.

Chung, Ch., Fabbri, A. G., van Westen, C. J.: Multivariate regression analysis for landslide hazard zonation, In Geographical Information Systems in Assessing Natural Hazards, edited by Carrara, A. and Guzzetti, F., Kluwer Academic Publishing, Dordrecht, The Netherlands, 7-142, 1995.

DMI (State Meteorological Organization): Temperature and Precipitation Records of Florya Station, DMI, Ankara, 1990.

Dokmeci, V. and Berkoz, L.: Residential - location preferences according to demographic characteristics in Istanbul, Landscape and Urban Planning, 48, 45-55, 2000.

Donati, L. and Turrini, M. C.: An objective method to rank the importance of the factors predisposing to landslides with the GIS methodology: application to an area of the Apennines (Valnerina; Perugia, Italy), Eng. Geol., 63, 277-289, 2002.

Duman, T. Y., Emre, Ö., Can, T., Ates, S., Kecer, M., Erkal, T., Durmaz, S., Dogan, A., Corekcioglu, E., Goktepe, A., Cicioglu, E., and Karakaya, F.: Turkish Landslide Inventory Mapping Project: Methodology and results on Zonguldak quadrangle (1/500000), Working in progress on the Geology of Turkey and its surroundings, In: Abstract Book of the 4th Int. Turkish Geology Symp., 24-28 September 2001, 392, 2001.

Duman, T. Y., Kecer, M., Ates, S., Emre, O., Gedik, I., Karakaya, F., Durmaz, S., Olgun, S., Sahin, H., and Gokmenoglu, O.: Istanbul Metropolu Batisindaki (Kucukcekmece - Silivri Catalca yoresi) Kentsel Gelisme Alanlarinin Yer Bilim Verileri, MTA, Special Publication No. $30 \quad 3,249,2004$ (in Turkish).

Duman, T. Y., Can, T., Emre, Ö., Kecer, M., Dogan, A., Ates, S., and Durmaz, S.: Landslide inventory of northwestern Anatolia, Engineering Geology, 77, 1/2, 99-114, 2005.

Ercanoglu, M. and Gokceoglu, C.: Assessment of landslide susceptibility for a landslide-prone

HESSD

2, 155-208, 2005

\section{Landslide susceptibility mapping of Cekmece}

T. Y. Duman et al.

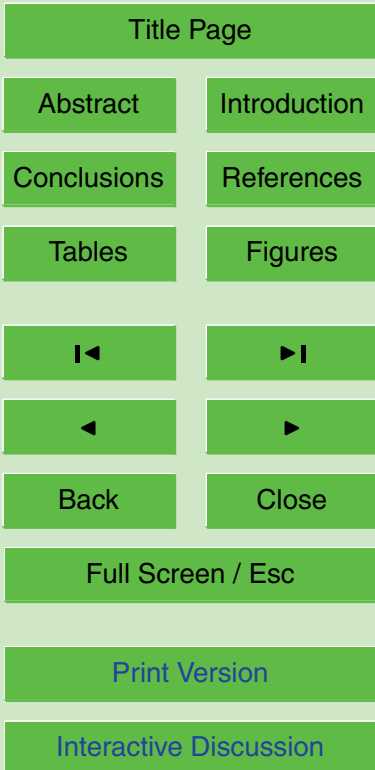

EGU 
area (North of Yenice, NW Turkey) by fuzzy approach, Environ. Geol., 41, 720-730, 2002.

Ercanoglu, M. and Gokceoglu, C.: Use of fuzzy relations to produce landslide susceptibility map of a landslide prone area (West Black Sea Region, Turkey), Engineering Geology, 75, 229-250, 2004.

5 Ercanoglu, M., Gokceoglu, C., and Van Asch, Th. W. J.: Landslide susceptibility zoning north of Yenice (NW Turkey) by multivariate statistical techniques, Natural Hazards, 32, 1-23, 2004.

Fabbri, A. G., Chung, C. J. F., Cendrero, A., and Remondo, J.: Is Prediction of Future Landslides Possible with a GIS?, Natural Hazards, 30, 487-499, 2003.

Fernandez, C. I., Del Castillo, T. F., El Hamdouni, R., and Montero, J. C.: Verification of landslide susceptibility mapping: A case study, Earth Surface Process and Landforms, 24, 537-544, 1999.

Gokceoglu, C. and Aksoy, H.: Landslide susceptibility mapping of the slopes in the residual soils of the Mengen region (Turkey) by deterministic stability analyses and image processing techniques, Eng. Geol., 44, 147-161, 1996.

Gomez, H. and Kavzoglu, T.: Assessment of shallow landslide susceptibility using artificial neural networks in Jabonosa River Basin, Venezuela, Engineering Geology, doi:10.1016/j.enggeo.2004.10.004, in press, 2004.

Gritzner, M. L., Marcus, W. A., Aspinall, R., and Custer, S. G.: Assessing landslide potential using GIS, soil wetness modeling and topographic attributes, Payette River, Idaho. Geomorphology, 37, 149-165, 2001.

Gupta, R. P. and Joshi, B. C.: Landslide hazard zoning using the GIS approach - A case study from the Ramganga Catchment, Himalayas, Engineering Geology, 28, 119-131, 1990.

Guzzetti, F., Carrara, A., Cardinali, M., and Reichenbach, P.: Landslide hazard evaluation: a review of current techniques and their application in a multi-scale study, Central Italy, Geomorphology, 31, 181-216, 1999.

Guzzetti, F., Cardinali, M., Reichenbach, P., and Carrara, A.: Comparing landslide maps: A case study in the Upper Tiber River Basin, Central Italy, Environmental Management, 25, 3, 247-263, 2000.

http://istanbul.meteor.gov.tr: Website of State Meteorological Organisation, 2004.

30 Ildir, B.: Turkiyede heyelanlarin dagilimi ve afetler yasasi ile ilgili uygulamalar, In: Proc. Of 2nd National Landslide Symposium of Turkey, Sakarya University, 1-9, 1995 (in Turkish).

Jade, S. and Sarkar, S.: Statistical models for slope instability classification, Engineering Geology, 36, 91-98, 1993.
HESSD

2, 155-208, 2005

\section{Landslide \\ susceptibility}

mapping of Cekmece

T. Y. Duman et al.

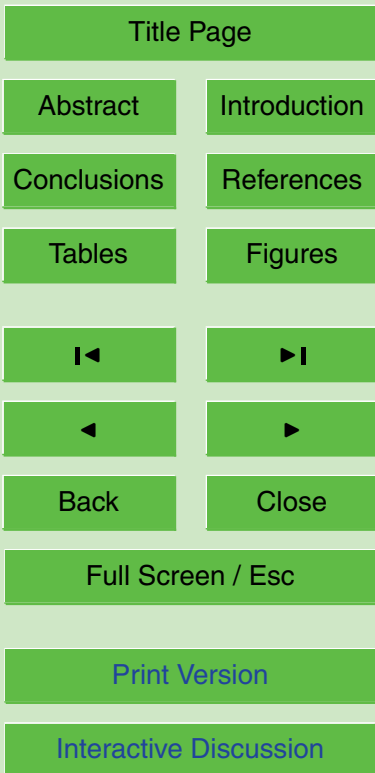

EGU 
Jager, S. and Wieczorek, G. F.: Landslide susceptibility in the Tully Valley Area, Finger Lakes Region, U.S. Geological Survey, Open-File Report 94-615, 1994.

Jakob, M.: The impacts of logging on landslide activity at Clayoquot Soung, British Columbia, Catena 38, 279-300, 2000.

5 Juang, C. H., Lee, D. H., and Sheu, C.: Mapping slope failure potential using fuzzy sets, J. Geotech. Eng. Div., ASCE 118, 475-493, 1992.

Koukis, G. and Ziourkas, C.: Slope instability phenomena in Greece: A statistical anlysis, Bulletin of International Association of Engineering Geologists, 43, 47-60, 1991.

Lee, S.: Application of Likelihood Ratio and Logistic Regression Models to Landslide Susceptibility Mapping Using GIS, Environmental Management, 34, 223-232, 2004.

Lee, S. and Min, K.: Statistical analysis of landslide susceptibility at Yongin, Korea Environ. Geol., 40, 1095-1113, 2001.

Lee, C. F., Ye, H., Yeung, M. R., Shan, X., and Chen, G.: AIGIS based methodology for natural terrain landslide susceptibility mapping in Hong Kong, Episodes, 24, 3, 150-159, 2001.

15 Lee, S., Ryu, J. H., Min, K., and Won, J. S.: Landslide susceptibility analysis using GIS and artificial neural network, Earth Surf., Processes Landf., 28, 1361-1376, 2003.

Lee, S., Ryu, J. H., Won, J. S., and Park, H. J.: Determination and application of the weights for landslide susceptibility mapping using an artificial neural network, Eng. Geol., 71, 289-302, 2004.

20 Luzi, L. and Pergalani, F.: Slope instability in static and dynamic conditions for urban planning: the "Oltre Po Pavese" case history (Regione Lombardia-Italy), Natural Hazards, 20, 57-82, 1999.

Maharaj, R.: Landslide processes and landslide susceptibility analysis from an upland watershed: A case study from St. Andrew, Jamaica,West Indies, Engineering Geology, 34, 53-79, 251993.

Nagarajan, R., Roy, A., Vinod Kumar, R., Mukherjee, A., and Khire, M. V.: Landslide hazard susceptibility mapping based on terrain and climatic factors for tropical monsoon regions, Bulletin of Engineering Geology and the Environment, 58, 275-287, 2000.

Negnevitsky, M.: Artificial Intelligence - A Guide to Intelligent Systems, Addison - Wesley Co., Great Britain, 394, 2002.

Pachauri, A. K. and Pant, M.: Landslide hazard mapping based on geological attributes, Engineering Geology, 32, 81-100, 1992.

Pachauri, A. K., Gupta, P. V., and Chander, R.: Landslide zoning in a part of the Garhwal

HESSD

2, 155-208, 2005

\section{Landslide susceptibility} mapping of Cekmece

T. Y. Duman et al.

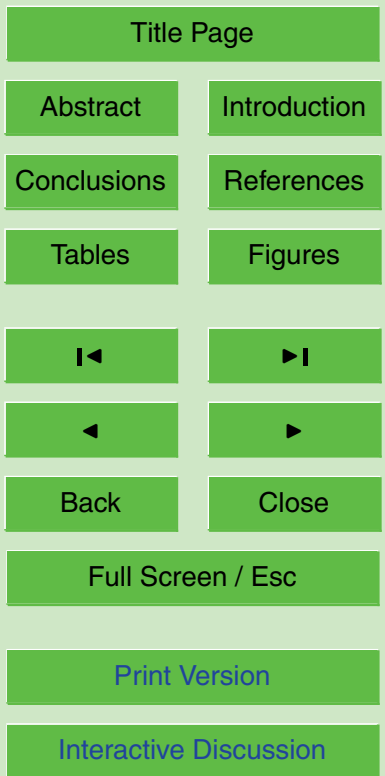

EGU 
Himalayas, Environmental Geology, 36, 3-4, 325-334, 1998.

Parsons, T., Stein, R. S., Barka, A. A., Dieterich, J. H.: Heightened odds of large earthquakes near Istanbul; an interaction - based probability calculation, Sci. Mag., April 28, 661-665, 2000.

5 Pistocchi, A., Luzi, L., and Napolitano, P.: The use of predictive modeling techniques for optimal exploitation of spatial databases: a case study in landslide hazard mapping with expert system - like methods, Environmental Geology, 41, 765-775, 2002.

Roth, R. A.: Factors affecting landslide susceptibility in SanMateo County, California, Bulletin of the Association of Engineering Geologists, XX, 4, 353-372, 1983.

10 Rowbotham, D. N. and Dudycha, D.: GIS modelling of slope stability in Phewa Tal watershed, Nepal, Geomorphology, 26, 151-170, 1998.

Safak, U., Avsar, N., and Meric, E.: Bati Bakirkoy (Istanbul) Tersiyer cokellerinin ostrakod ve formanifer toplulugu, MTA Journal, 121, 17-31, 1999 (in Turkish).

Soeters, R. S. and Van Westen, C. J.: Slope instability recognition, analysis and zonation, 15 In: Landslides: Investigation and Mitigation, edited by Turner A. K. and Schuster, R. L., Transportation Research Board, Special Report, National Academy Press, Washington, C, 247, 129-177, 1996.

Soysal, H., Sipahioglu, S., Kolcak, D., and Altinok, Y.: Tuurkiye ve Cevresinin Tarihsel Deprem Katalogu (MO 2100-MS 1900), TUBITAK project Tbag 341, Istanbul, 1981.

Suzen, M. L. and Doyuran, V.: A comparison of the GIS based landslide susceptibility assessment methods: multivariate versus bivariate, Environmental Geology, 45, 665-679, 2004a.

Suzen, M. L. and Doyuran, V.: Data driven bivariate landslide susceptibility assessment using geographical information systems: a method and application to Asarsuyu catchment, Turkey, Eng. Geol., 71, 303-321, 2004b.

Todd, D. C.: Groundwater Hydrology, John Wiley and Sons, New York, 336, 1980.

Turrini, M. C. and Visintainer, P.: Proposal of a method to define areas of landslide hazard and application to an area of the Dolomites, Italy, Engineering Geology, 50, 255-265, 1998.

Van Westen, C. J., Seijmonsbergen, A. C., and Mantovani, F.: Comparing landslide hazard maps, Natural Hazards, 20, 137-158, 1999.

30 Varnes, D. J.: Slope movement types and processes, In: Landslides Analysis and Control, edited by Schuster, R. L. and Krizek, R. J., Special Report, Transportation Research Board, National Academy of Sciences, New York, 176, 12-33, 1978.

Wachal, D. J. and Hudak, P. F.: Mapping landslide susceptibility in Travis County, Texas, USA,

\section{HESSD}

2, 155-208, 2005

\section{Landslide susceptibility mapping of Cekmece}

T. Y. Duman et al.

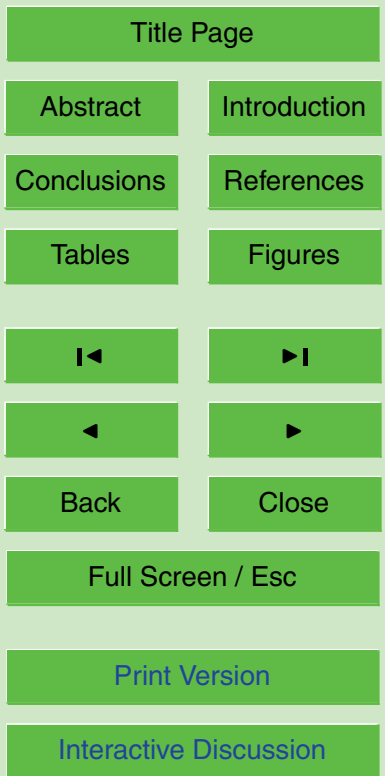

EGU 
Geo. Journal, 51, 245-253, 2000.

WP/WLI (Working Party on World Landslide Inventory): A suggested method for describing the activity of a landslide, Bull. Int. Assoc. Eng. Geol., 47, 53-57, 1993.

Zezere, J. L.: Landslide susceptibility assessment considering landslide typology. A case study 5 in the area north of Lisbon (Portugal), Natural Hazards and Earth System Sciences, 2, 7382, 2002, SRef-ID: 1684-9981/nhess/2002-2-73.

Zezere, J. L., Ferreira, A. B., and Rodrigues, M. L.: Landslides in the North of Lisbon Region (Portugal): Conditioning and triggering factors, Physical and Chemical Earth (A), 24, 10, 925-934, 1999.

\section{HESSD}

2, 155-208, 2005

\section{Landslide \\ susceptibility mapping of Cekmece}

T. Y. Duman et al.

\section{Title Page}

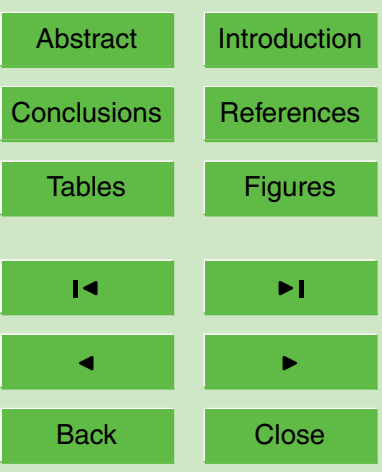

Full Screen / Esc

Print Version

Interactive Discussion 
Table 1. The data employed in the analyses and the results obtained from the conditional probability approach.

\begin{tabular}{llllllll}
\hline \multicolumn{7}{c}{$\begin{array}{c}\text { Landslide area in } \\
\text { parameter class }\end{array}$} \\
Parameter & $\begin{array}{r}\text { Parameter class area } \\
\text { Pix. Count. }\end{array}$ & $\mathrm{m}^{2}$ & Pix. Count. & $\mathrm{m}^{2}$ & $\mathrm{P}\left(\mathrm{A} / \mathrm{B}_{i}\right)$ & $\mathrm{P}\left(\mathrm{B}_{i}\right)$ & $\mathrm{P}(\mathrm{A})$ \\
\hline Slope $\left(^{\circ}\right)$ & & & & & & & \\
$0-5$ & 152235 & 95146875 & 13078 & 8173750 & 0.085907 & 0.543440 & 0.046685 \\
$5-10$ & 96444 & 60277500 & 26665 & 16665625 & 0.276482 & 0.344281 & 0.095187 \\
$10-15$ & 22221 & 13888125 & 9389 & 5868125 & 0.422528 & 0.079323 & 0.033516 \\
$15-20$ & 5959 & 3724375 & 2851 & 1781875 & 0.478436 & 0.021272 & 0.010177 \\
$20-25$ & 1980 & 1237500 & 1011 & 631875 & 0.510606 & 0.007068 & 0.003609 \\
$25-30$ & 767 & 479375 & 402 & 251250 & 0.524120 & 0.002738 & 0.001435 \\
$30-50$ & 520 & 325000 & 275 & 171875 & 0.528846 & 0.001856 & 0.000982 \\
$50-90$ & 6 & 3750 & 3 & 1875 & 0.500000 & 0.000021 & 0.000011 \\
\hline Aspect $\left(^{\circ}\right)$ & & & & & & & \\
$0-45$ & 18323 & 11451875 & 4075 & 2546875 & 0.222398 & 0.065408 & 0.014547 \\
$45-90$ & 38150 & 23843750 & 6521 & 4075625 & 0.170931 & 0.136186 & 0.023278 \\
$90-135$ & 33985 & 21240625 & 5203 & 3251875 & 0.153097 & 0.121318 & 0.018573 \\
$135-180$ & 29140 & 18212500 & 6671 & 4169375 & 0.228929 & 0.104022 & 0.023814 \\
$180-225$ & 29119 & 18199375 & 7733 & 4833125 & 0.265565 & 0.103947 & 0.027605 \\
$225-270$ & 41964 & 26227500 & 7706 & 4816250 & 0.183634 & 0.149801 & 0.027508 \\
$270-315$ & 33657 & 21035625 & 6920 & 4325000 & 0.205604 & 0.120147 & 0.024703 \\
$315-360$ & 17597 & 10998125 & 3693 & 2308125 & 0.209865 & 0.062817 & 0.013183 \\
-1 & 38197 & 23873125 & 5152 & 3220000 & 0.134880 & 0.136354 & 0.018391 \\
\hline
\end{tabular}

\section{HESSD}

2, 155-208, 2005

\section{Landslide susceptibility mapping of Cekmece}

T. Y. Duman et al.

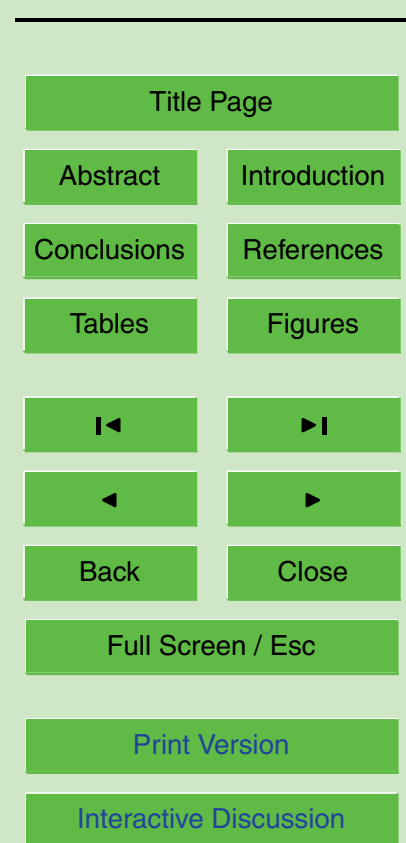

EGU 
Table 1. Continued.

\begin{tabular}{|c|c|c|c|c|c|c|c|}
\hline \multirow[b]{2}{*}{ Parameter } & \multicolumn{2}{|c|}{ Parameter class area } & \multicolumn{2}{|c|}{$\begin{array}{l}\text { Landslide area in } \\
\text { parameter class }\end{array}$} & \multirow[b]{2}{*}{$\mathrm{P}\left(\mathrm{A} / \mathrm{B}_{i}\right)$} & \multirow[b]{2}{*}{$\mathrm{P}\left(\mathrm{B}_{i}\right)$} & \multirow[b]{2}{*}{$P(A)$} \\
\hline & Pix. Count. & $\mathrm{m}^{2}$ & Pix. Count. & $\mathrm{m}^{2}$ & & & \\
\hline \multicolumn{8}{|l|}{ Altitude (m) } \\
\hline $0-25$ & 28974 & 18108750 & 4862 & 3038750 & 0.167806 & 0.103430 & 0.017356 \\
\hline $25-50$ & 37867 & 23666875 & 9930 & 6206250 & 0.262234 & 0.135176 & 0.035448 \\
\hline $50-75$ & 37542 & 23463750 & 9526 & 5953750 & 0.253742 & 0.134015 & 0.034005 \\
\hline $75-100$ & 43156 & 26972500 & 8829 & 5518125 & 0.204583 & 0.154056 & 0.031517 \\
\hline $100-125$ & 43277 & 27048125 & 8164 & 5102500 & 0.188645 & 0.154488 & 0.029143 \\
\hline $125-150$ & 39680 & 24800000 & 7352 & 4595000 & 0.185282 & 0.141648 & 0.026245 \\
\hline $150-175$ & 32089 & 20055625 & 4467 & 2791875 & 0.139207 & 0.114550 & 0.015946 \\
\hline $175-200$ & 17547 & 10966875 & 544 & 340000 & 0.031002 & 0.062638 & 0.001942 \\
\hline \multicolumn{8}{|l|}{ Lithology } \\
\hline Qa & 15644 & 9777500 & 1127 & 704375 & 0.072040 & 0.055845 & 0.004023 \\
\hline Tek & 1613 & 1008125 & 0 & 0 & 0.000000 & 0.005758 & 0.000000 \\
\hline Teoi & 43337 & 27085625 & 1810 & 1131250 & 0.041766 & 0.154702 & 0.006461 \\
\hline Teoi2 & 478 & 298750 & 66 & 41250 & 0.138075 & 0.001706 & 0.000236 \\
\hline Teoiy & 1035 & 646875 & 0 & 0 & 0.000000 & 0.003695 & 0.000000 \\
\hline Tmb & 56253 & 35158125 & 4473 & 2795625 & 0.079516 & 0.200809 & 0.015967 \\
\hline Tme & 71366 & 44603750 & 13617 & 8510625 & 0.190805 & 0.254758 & 0.048609 \\
\hline To & 14336 & 8960000 & 5706 & 3566250 & 0.398019 & 0.051176 & 0.020369 \\
\hline Tod & 20650 & 12906250 & 4728 & 2955000 & 0.228959 & 0.073715 & 0.016878 \\
\hline Toda & 34254 & 21408750 & 17151 & 10719375 & 0.500701 & 0.122278 & 0.061225 \\
\hline Tos & 21166 & 13228750 & 4996 & 3122500 & 0.236039 & 0.075557 & 0.017834 \\
\hline
\end{tabular}

HESSD

2, 155-208, 2005

\section{Landslide \\ susceptibility mapping of Cekmece}

T. Y. Duman et al.

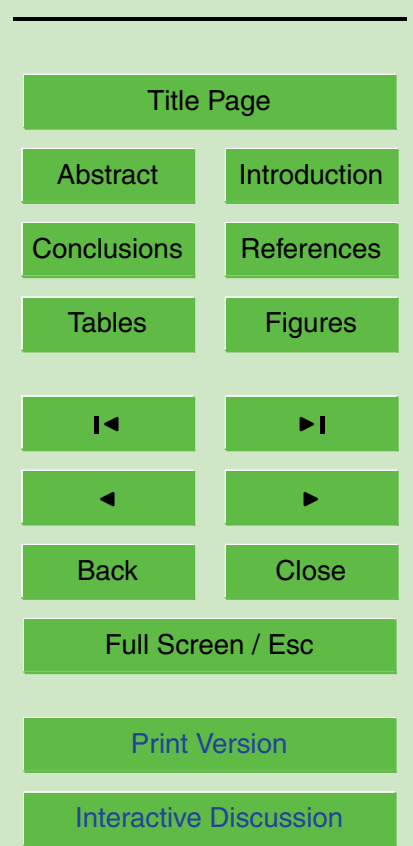

EGU 
Table 1. Continued.

\begin{tabular}{llllllll}
\hline \multicolumn{7}{c}{ Parameter class area } & \multicolumn{2}{c}{$\begin{array}{c}\text { Landslide area in } \\
\text { parameter class }\end{array}$} \\
Parameter & Pix. Count. & $\mathrm{m}^{2}$ & Pix. Count. & $\mathrm{m}^{2}$ & $\mathrm{P}\left(\mathrm{A} / \mathrm{B}_{i}\right)$ & $\mathrm{P}\left(\mathrm{B}_{i}\right)$ & $\mathrm{P}(\mathrm{A})$ \\
\hline Geomorphology & & & & & & & \\
AB & 385 & 240625 & 0 & 0 & 0.000000 & 0.001374 & 0.000000 \\
By & 128 & 80000 & 69 & 43125 & 0.539063 & 0.000457 & 0.000246 \\
Db & 231 & 144375 & 76 & 47500 & 0.329004 & 0.000825 & 0.000271 \\
Dko & 1754 & 1096250 & 57 & 35625 & 0.032497 & 0.006261 & 0.000203 \\
Dp & 207 & 129375 & 0 & 0 & 0.000000 & 0.000739 & 0.000000 \\
EKSY & 1004 & 627500 & 0 & 0 & 0.000000 & 0.003584 & 0.000000 \\
EL & 1296 & 810000 & 6 & 3750 & 0.004630 & 0.004626 & 0.000021 \\
HB & 1387 & 866875 & 144 & 90000 & 0.103821 & 0.004951 & 0.000514 \\
PH & 3511 & 2194375 & 1071 & 669375 & 0.305041 & 0.012533 & 0.003823 \\
UMAY & 1356 & 847500 & 1 & 625 & 0.000737 & 0.004841 & 0.000004 \\
UMDY & 67225 & 42015625 & 1566 & 978750 & 0.023295 & 0.239976 & 0.005590 \\
Vt & 9845 & 6153125 & 420 & 262500 & 0.042661 & 0.035144 & 0.001499 \\
Y & 184517 & 115323125 & 50242 & 31401250 & 0.272289 & 0.658679 & 0.179351 \\
YK & 91 & 56875 & 21 & 13125 & 0.230769 & 0.000325 & 0.000075 \\
\hline Dist. Fr. Faults $(\mathrm{m})$ & & & & & & & \\
0-200 & 22328 & 13955000 & 1009 & 630625 & 0.045190 & 0.079705 & 0.003602 \\
200-400 & 19180 & 11987500 & 1150 & 718750 & 0.059958 & 0.068468 & 0.004105 \\
$400-600$ & 14661 & 9163125 & 1251 & 781875 & 0.085328 & 0.052336 & 0.004466 \\
$600-800$ & 13224 & 8265000 & 1567 & 979375 & 0.118497 & 0.047206 & 0.005594 \\
$800-1000$ & 11443 & 7151875 & 1604 & 1002500 & 0.140173 & 0.040849 & 0.005726 \\
\hline
\end{tabular}

HESSD

2, 155-208, 2005

\section{Landslide susceptibility mapping of Cekmece}

T. Y. Duman et al.

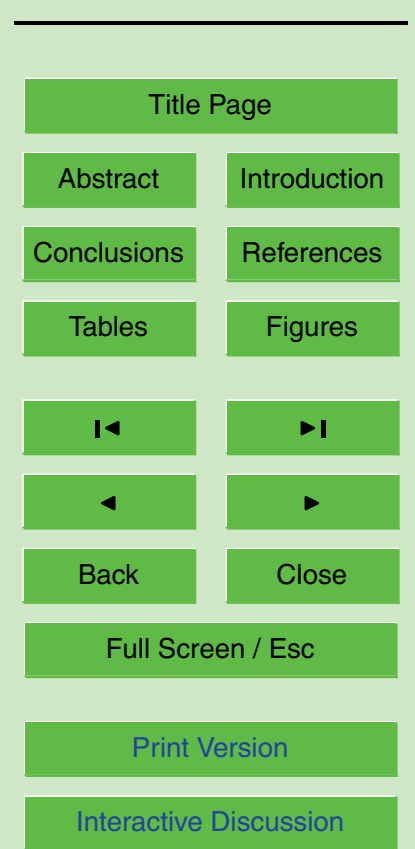

EGU 


\section{HESSD}

2, 155-208, 2005

Table 1. Continued.

\begin{tabular}{llllllll}
\hline \multicolumn{7}{c}{} & \multicolumn{7}{c}{$\begin{array}{c}\text { Landslide area in } \\
\text { parameter class }\end{array}$} \\
& $\begin{array}{l}\text { Parameter class area } \\
\text { Parameter }\end{array}$ & $\begin{array}{l}\text { Pix. Count. } \\
\mathrm{m}^{2}\end{array}$ & Pix. Count. & $\mathrm{m}^{2}$ & $\mathrm{P}\left(\mathrm{A} / \mathrm{B}_{i}\right)$ & $\mathrm{P}\left(\mathrm{B}_{i}\right)$ & $\mathrm{P}(\mathrm{A})$ \\
\hline Dist. Fr. Drain. (m) & & & & & & & \\
$0-25$ & 6855 & 4284375 & 1066 & 666250 & 0.155507 & 0.024471 & 0.003805 \\
$25-50$ & 6810 & 4256250 & 1571 & 981875 & 0.230690 & 0.024310 & 0.005608 \\
$50-75$ & 6714 & 4196250 & 1763 & 1101875 & 0.262586 & 0.023967 & 0.006293 \\
$75-100$ & 6590 & 4118750 & 1792 & 1120000 & 0.271927 & 0.023525 & 0.006397 \\
$100-125$ & 6578 & 4111250 & 1691 & 1056875 & 0.257069 & 0.023482 & 0.006036 \\
\hline Dist. Fr. Roads $(\mathrm{m})$ & & & & & & & \\
$0-10$ & 11531 & 7206875 & 1308 & 817500 & 0.113433 & 0.041163 & 0.004669 \\
$10-20$ & 11197 & 6998125 & 1217 & 760625 & 0.108690 & 0.039970 & 0.004344 \\
$20-30$ & 10141 & 6338125 & 1219 & 761875 & 0.120205 & 0.036201 & 0.004352 \\
$30-40$ & 9972 & 6232500 & 1192 & 745000 & 0.119535 & 0.035598 & 0.004255 \\
$40-50$ & 8976 & 5610000 & 1171 & 731875 & 0.130459 & 0.032042 & 0.004180 \\
\hline Relative permeability & & & & & & & \\
Low (or impermeable) & 113571 & 70981875 & 29729 & 18580625 & 0.261766 & 0.405420 & 0.106125 \\
Moderate & 20650 & 12906250 & 4728 & 2955000 & 0.228959 & 0.073715 & 0.016878 \\
High & 145911 & 91194375 & 19217 & 12010625 & 0.131704 & 0.520865 & 0.068600 \\
\hline
\end{tabular}

\section{Landslide \\ susceptibility mapping of Cekmece}

T. Y. Duman et al.

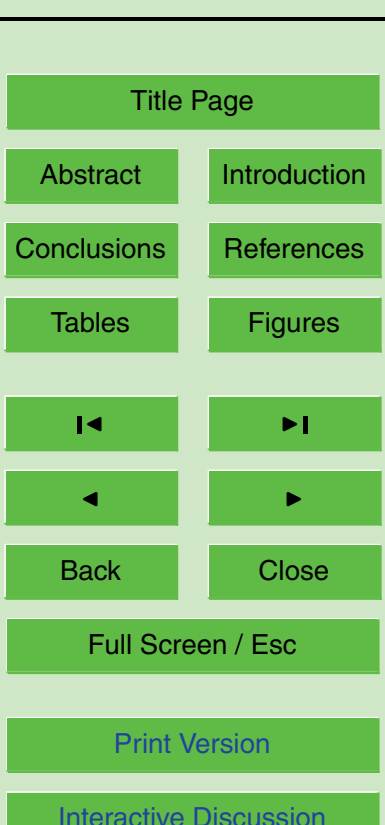

EGU 


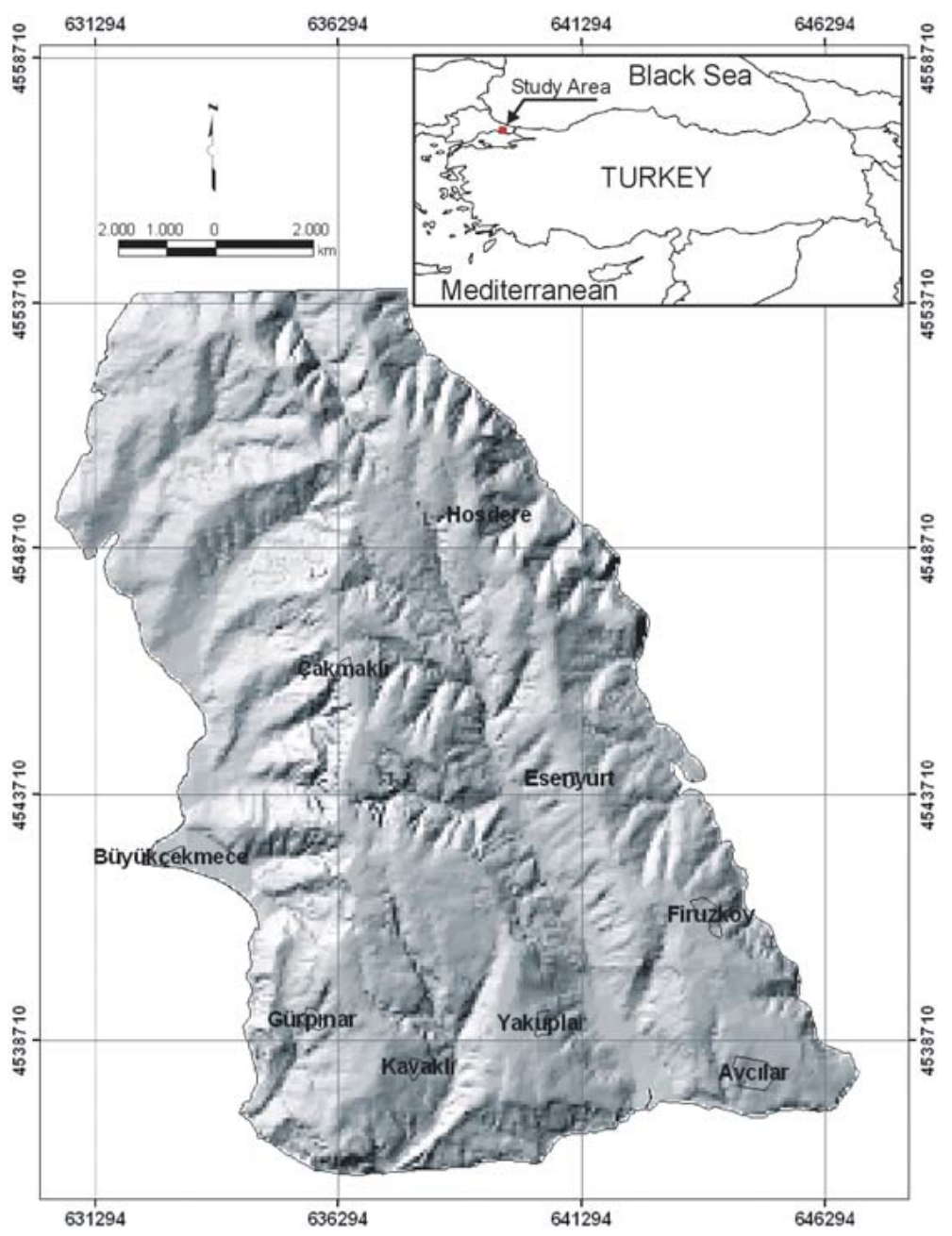

HESSD

2, 155-208, 2005

\section{Landslide} susceptibility mapping of Cekmece

T. Y. Duman et al.

Title Page

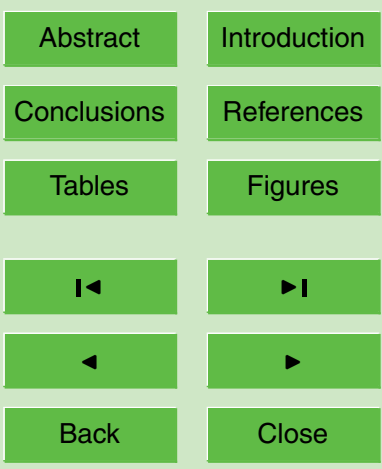

Full Screen / Esc

Print Version

Interactive Discussion

EGU

Fig. 1. Location map of the study area. 


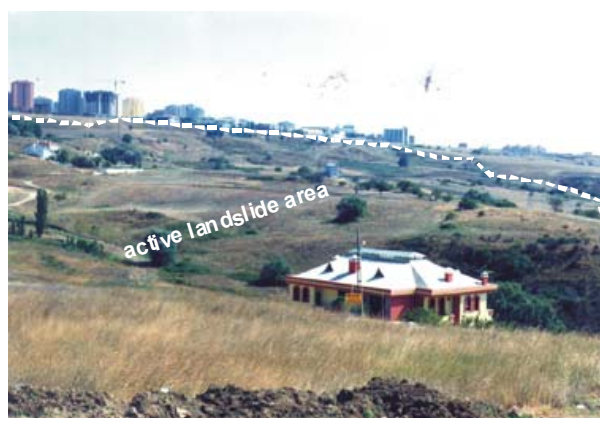

\section{HESSD}

2, 155-208, 2005

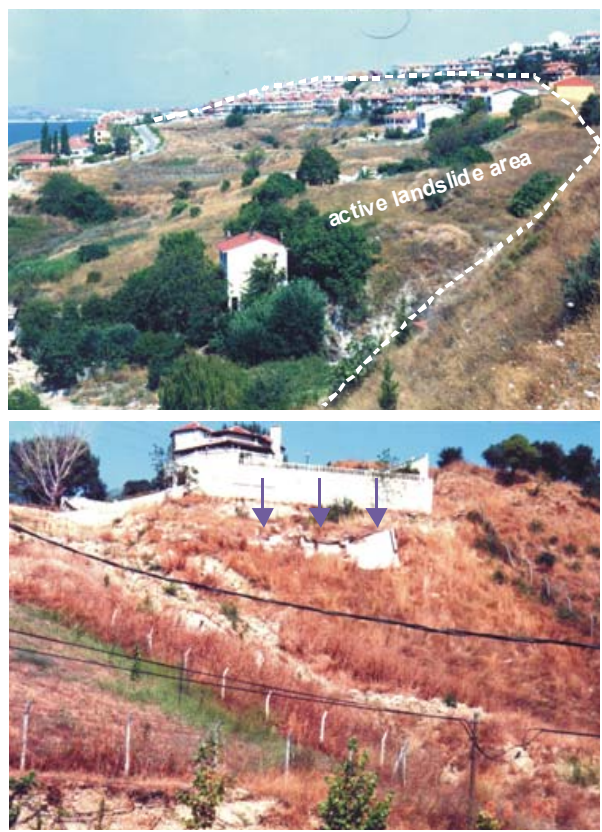

Title Page

Abstract

Conclusions

Tables

14

4

Back

Full Screen / Esc

Print Version

Interactive Discussion

Fig. 2. Some typical views from the study area (many buildings were constructed in the active landslides). 


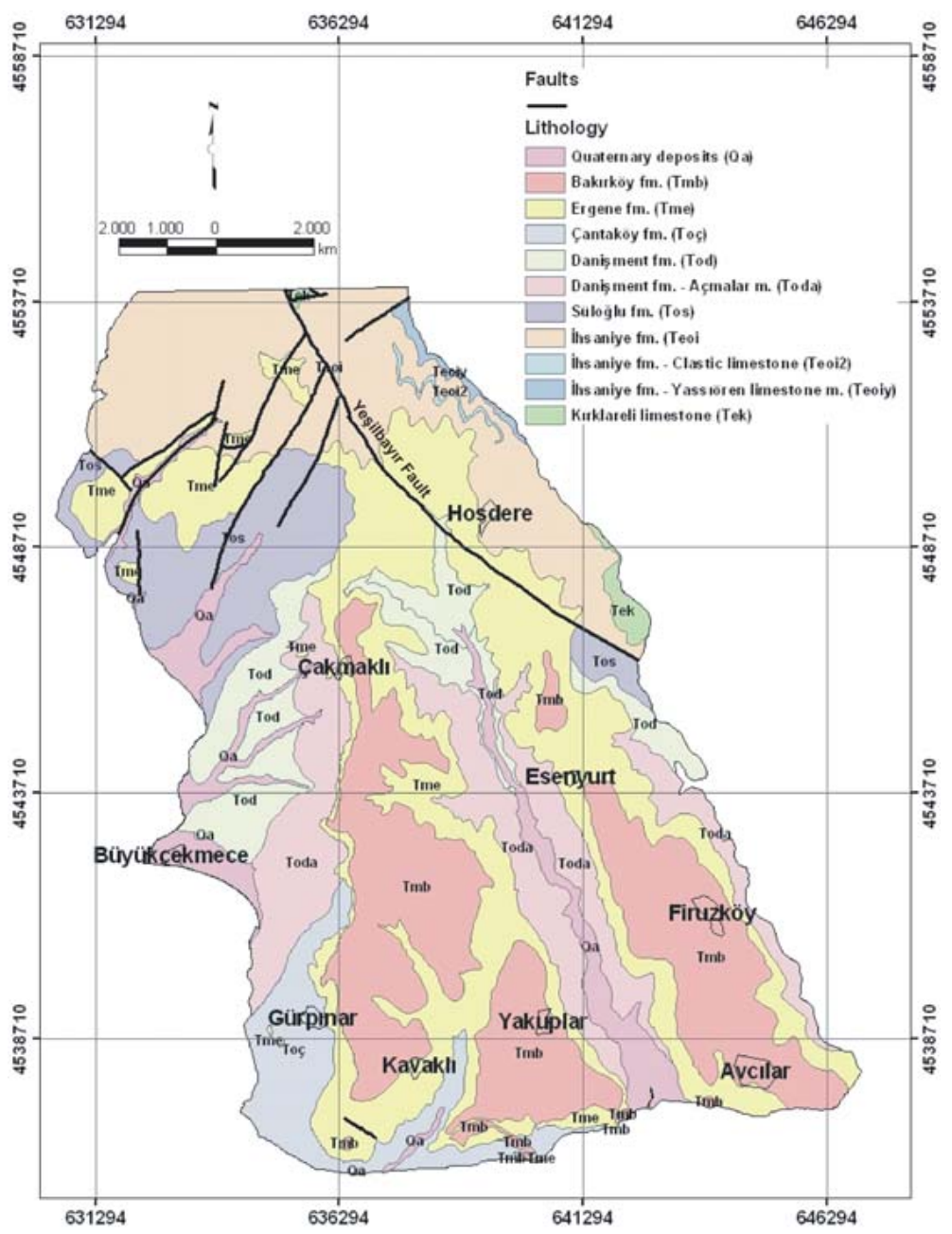

HESSD

2, 155-208, 2005

\section{Landslide susceptibility mapping of Cekmece}

T. Y. Duman et al.

\section{Title Page}

\begin{tabular}{|c|c|}
\hline Abstract & Introduction \\
\hline Conclusions & References \\
\hline Tables & Figures \\
\hline 14 & \\
\hline & \\
\hline Back & Close \\
\hline
\end{tabular}

Full Screen / Esc

Print Version

Interactive Discussion

EGU

Fig. 3. Geological map of the study area (Duman et al., 2004a). 


\section{HESSD}

2, 155-208, 2005

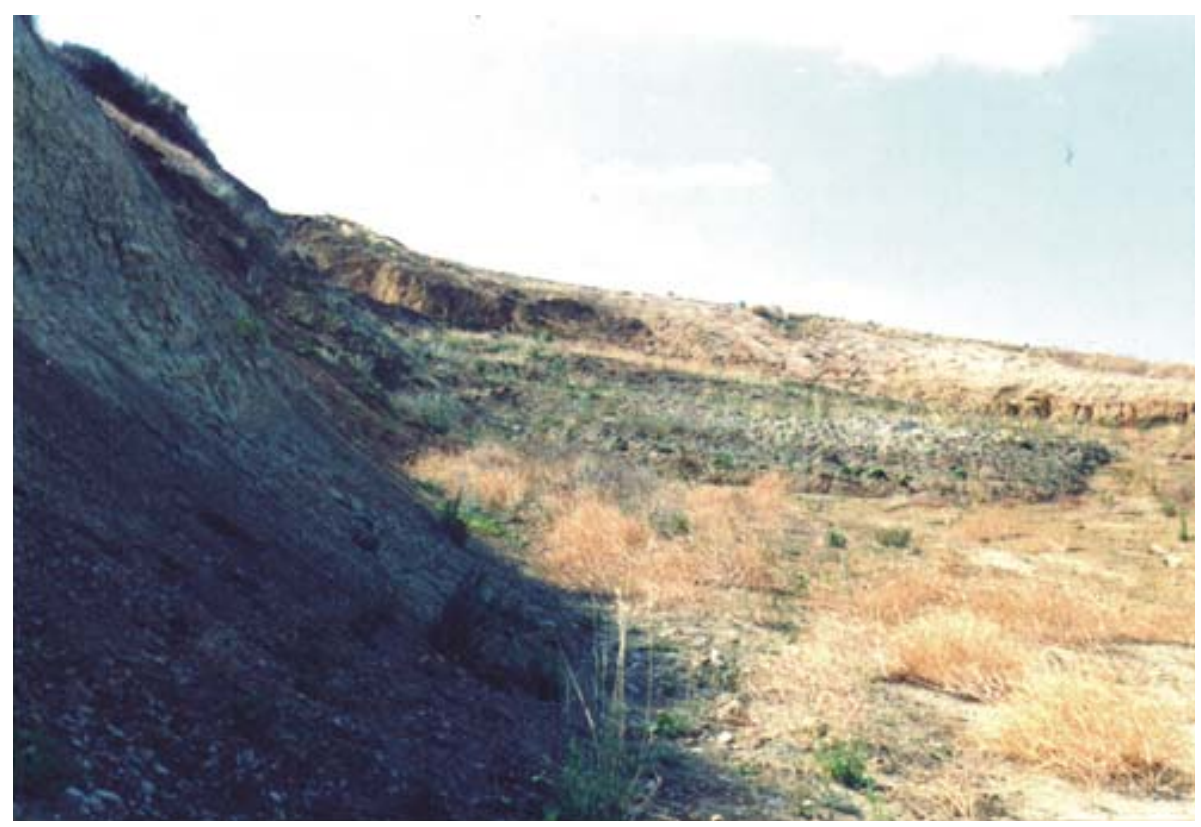

\section{Landslide} susceptibility mapping of Cekmece

T. Y. Duman et al.

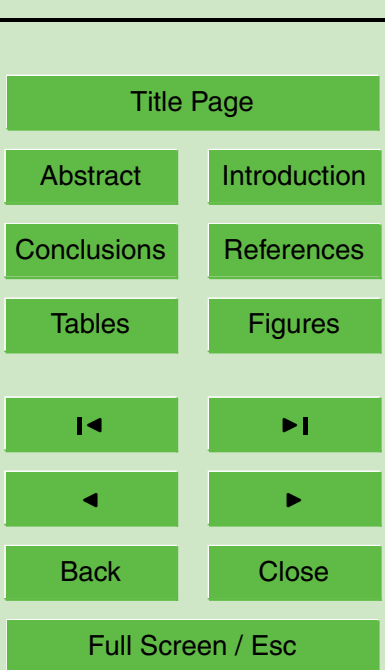

Fig. 4. A close view from the Danisment formation.

Print Version

Interactive Discussion 

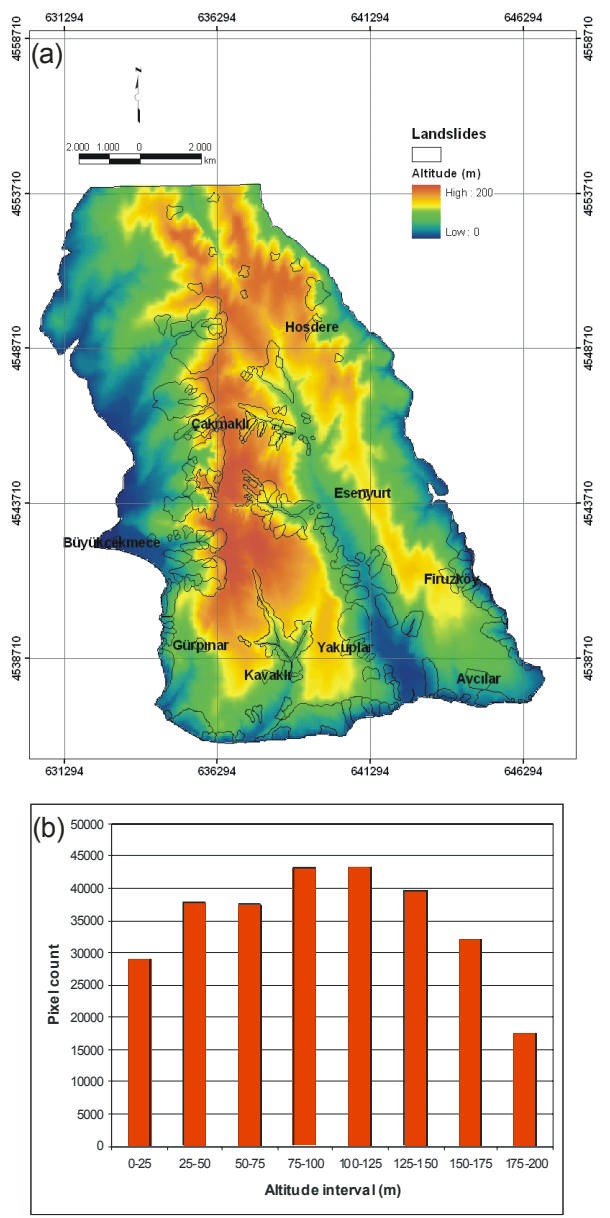

\section{HESSD}

2, 155-208, 2005

\section{Landslide \\ susceptibility mapping of Cekmece}

T. Y. Duman et al.

\section{Title Page}

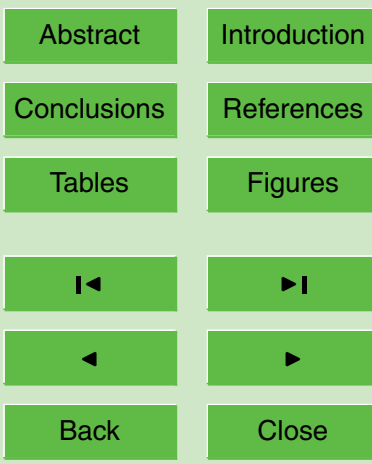

Full Screen / Esc

Print Version

Interactive Discussion

Fig. 5. (a) Altitude map of the study area and (b) Histogram showing the distribution of altitude values of the study area. 


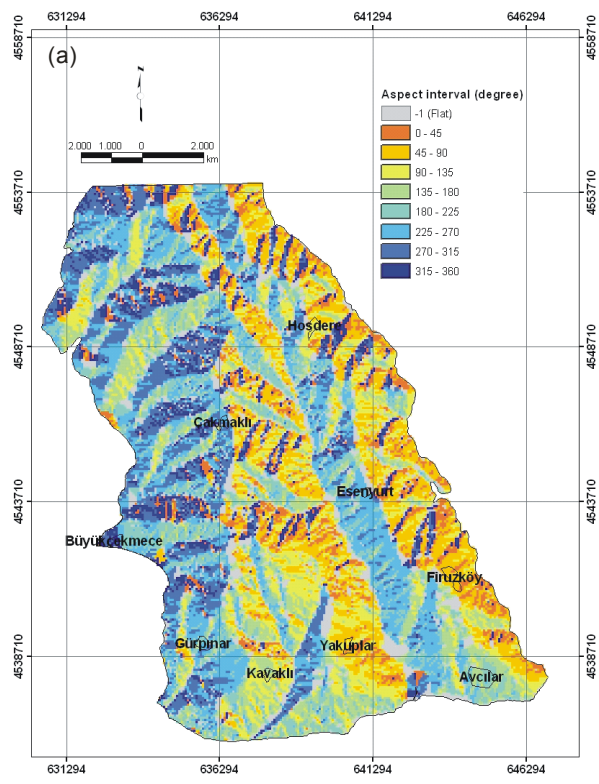

\section{HESSD}

2, 155-208, 2005

\section{Landslide \\ susceptibility mapping of Cekmece}

T. Y. Duman et al.

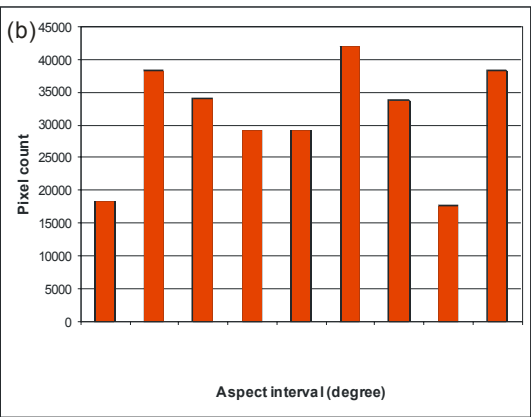

Title Page

Abstract

Conclusions

Tables

14

4

Back

Full Screen / Esc

Print Version

Interactive Discussion

Fig. 6. (a) Aspect map of the study area and (b) Histogram showing the distribution of the aspect values of the study area. 


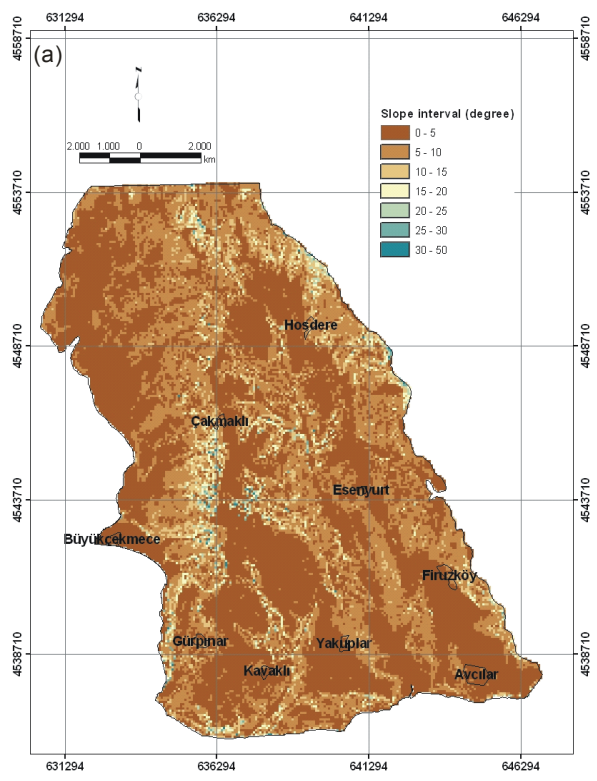

\section{HESSD}

2, 155-208, 2005

\section{Landslide \\ susceptibility mapping of Cekmece}

T. Y. Duman et al.

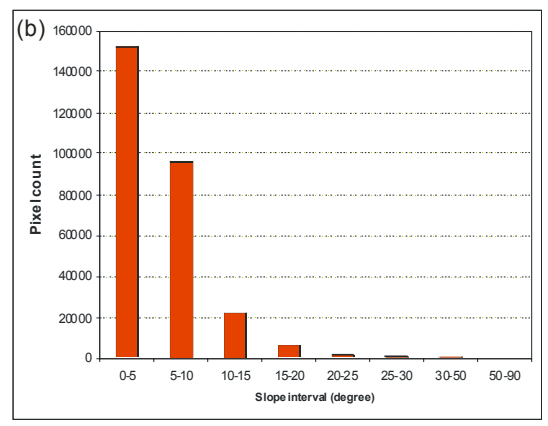

Title Page

Abstract Introduction

Conclusions References

Tables

Figures

14

$>1$

4

Back

Close

Full Screen / Esc

Print Version

Interactive Discussion

Fig. 7. (a) Slope map of the study area and (b) Histogram showing the distribution of the slope values of the study area. 


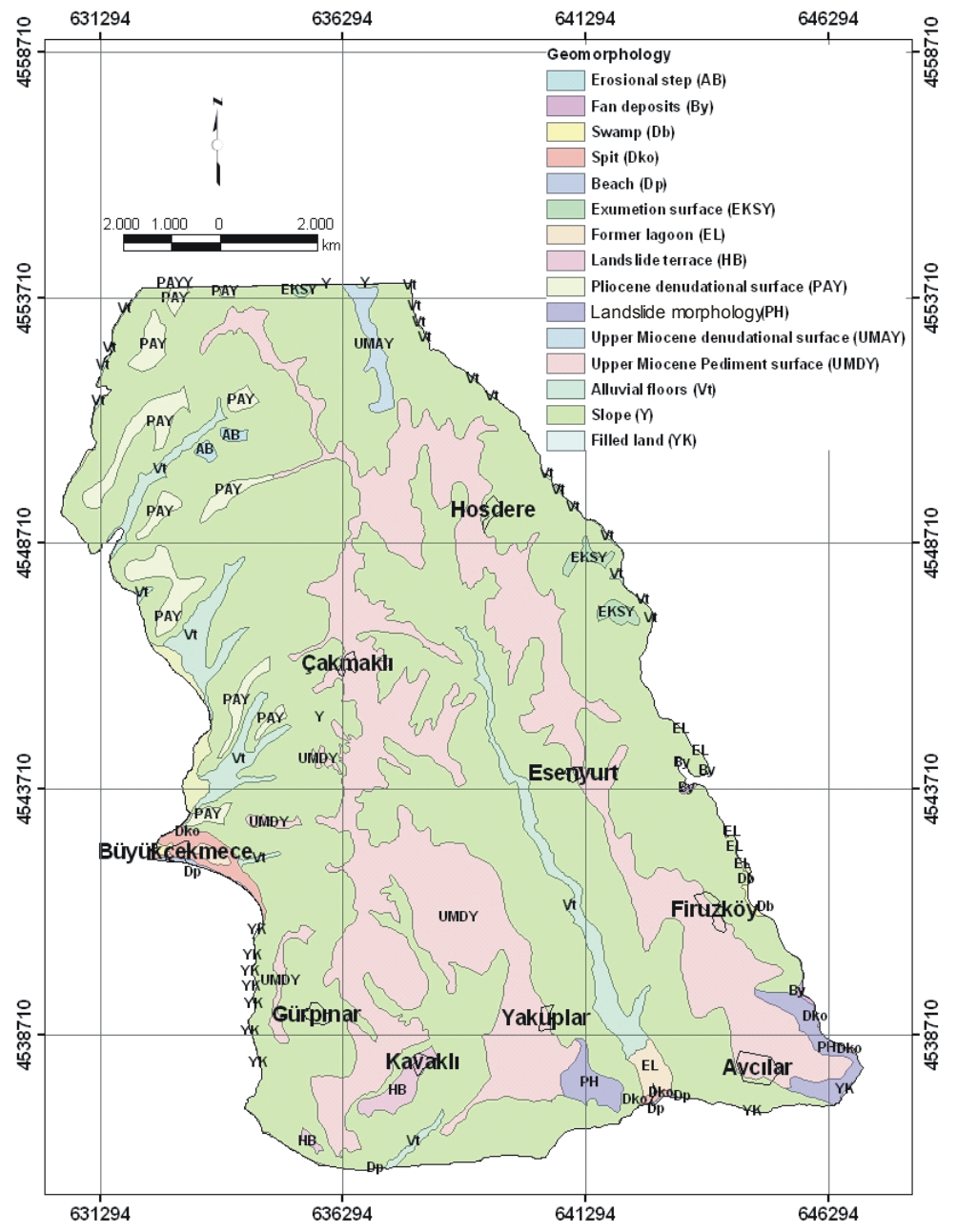

HESSD

2, 155-208, 2005

\section{Landslide susceptibility mapping of Cekmece}

T. Y. Duman et al.

Title Page

\begin{tabular}{|c|c|}
\hline Abstract & Introduction \\
\hline Conclusions & References \\
\hline Tables & Figures \\
\hline I4 & \\
\hline & \\
\hline Back & Close \\
\hline
\end{tabular}

\section{Full Screen / Esc}

Print Version

Interactive Discussion

Fig. 8. Geomorpholoy map of the study area (Duman et al., 2004a). 


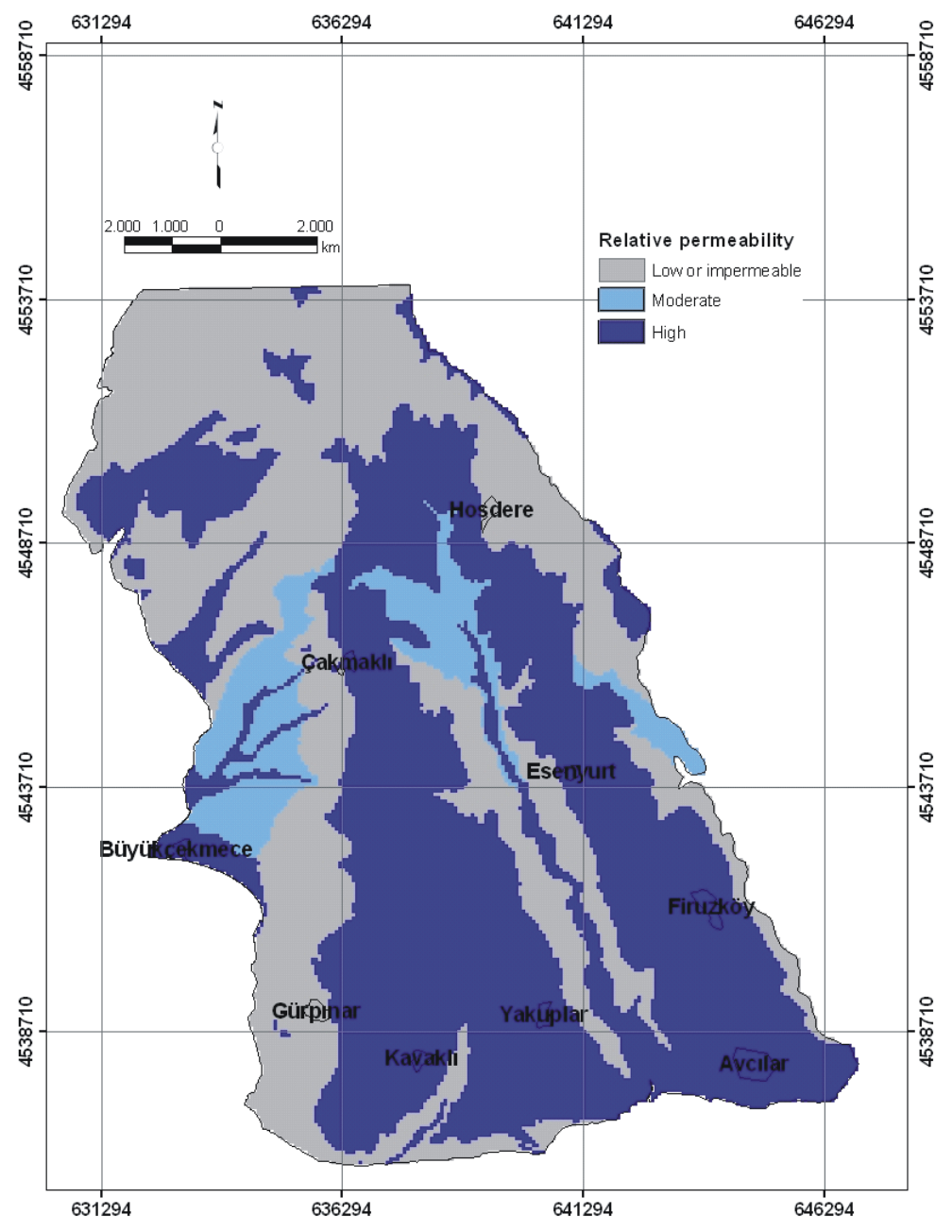

HESSD

2, 155-208, 2005

\section{Landslide} susceptibility mapping of Cekmece

T. Y. Duman et al.

\section{Title Page}

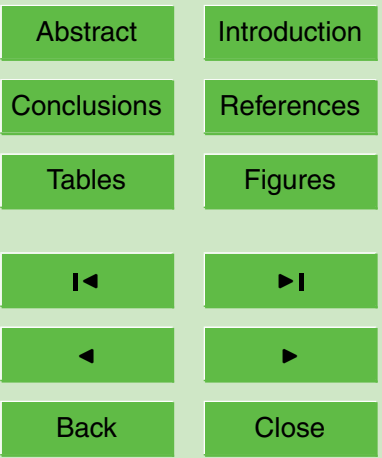

Full Screen / Esc

Print Version

Interactive Discussion 


\section{HESSD}

2, 155-208, 2005

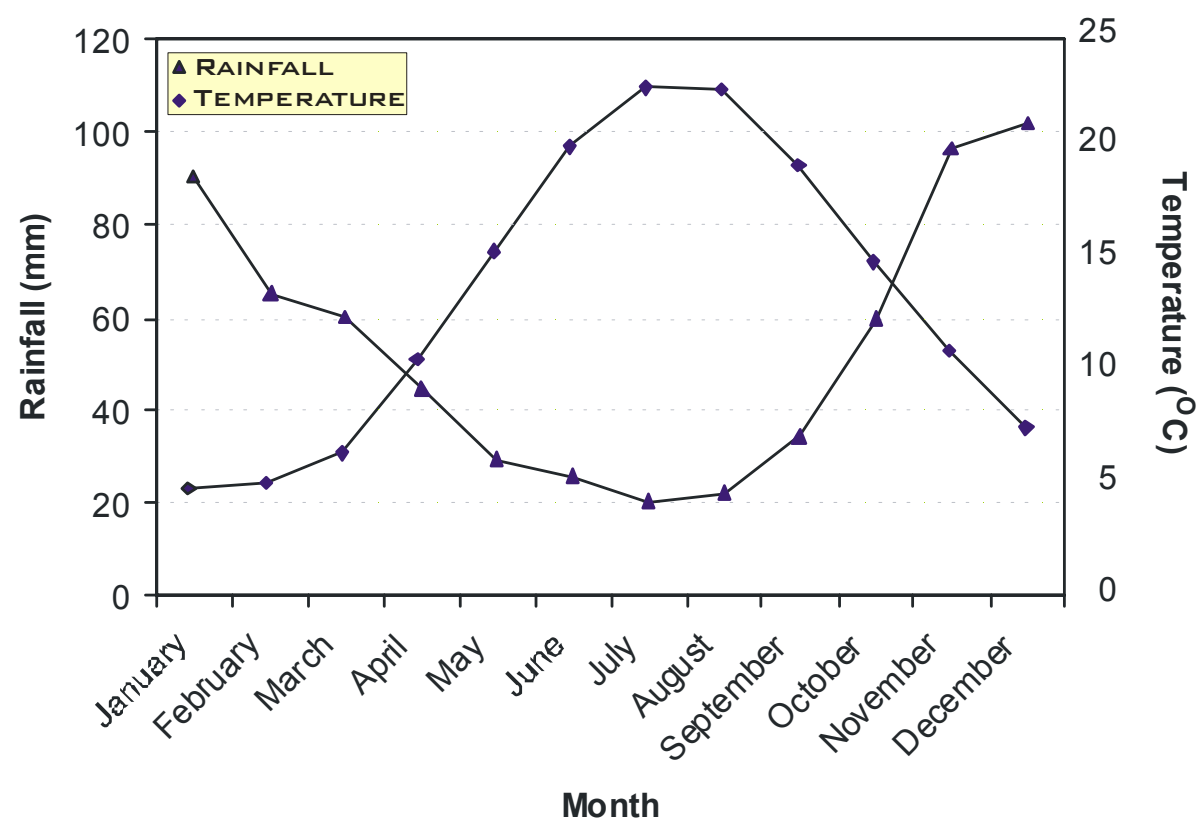

Fig. 10. Average annual rainfall and temperature graph of the data from Florya Meteorology Station.

\section{Landslide} susceptibility mapping of Cekmece

T. Y. Duman et al.

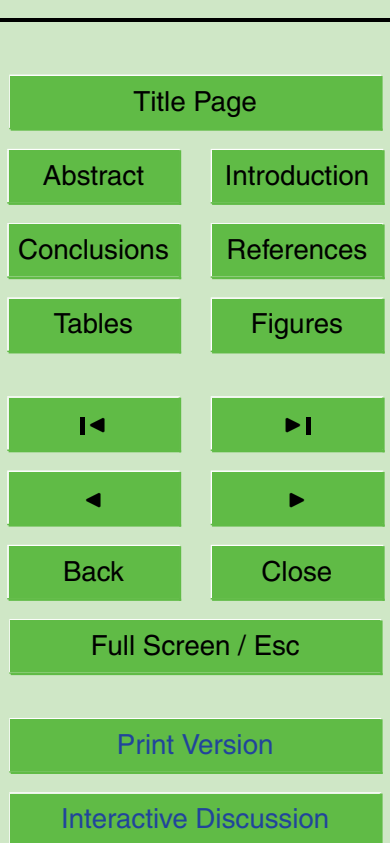




\section{HESSD}

2, 155-208, 2005

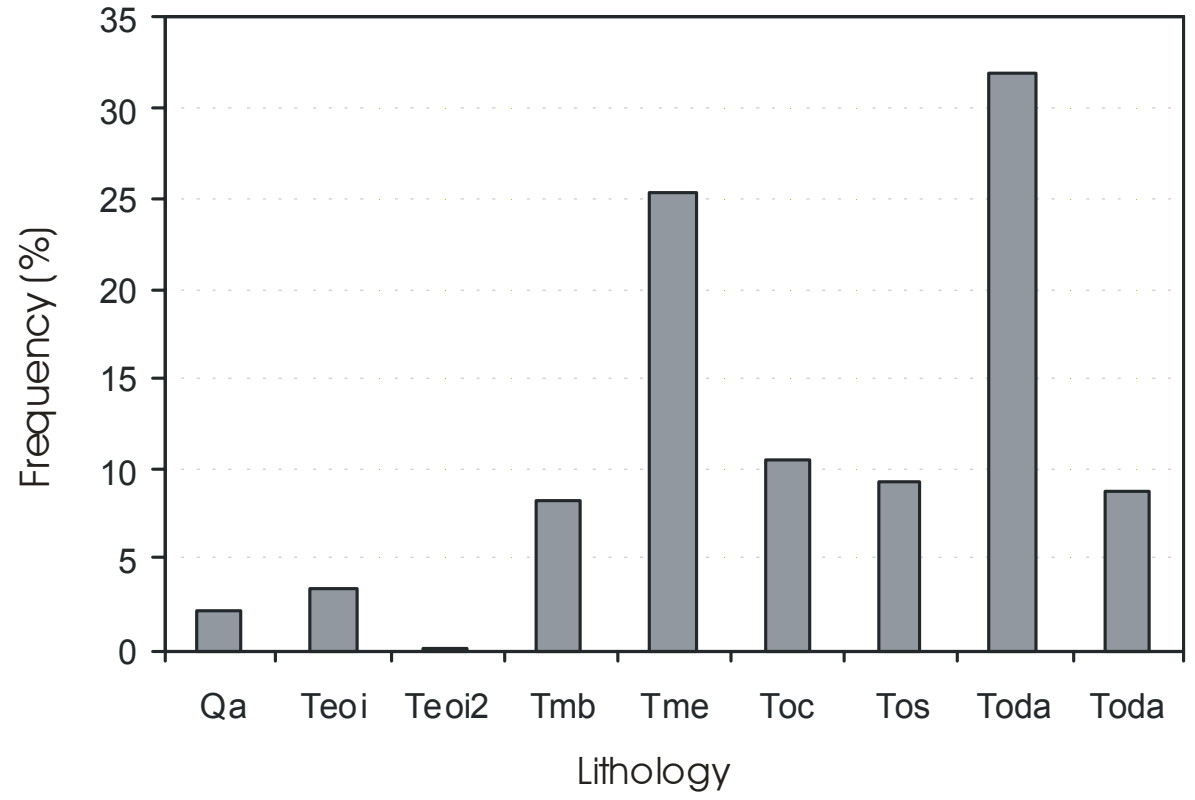

Fig. 11. Histogram illustrating the distribution of the landslides with respect to the lithologies at the study area.

\section{Landslide}

susceptibility mapping of Cekmece

T. Y. Duman et al.

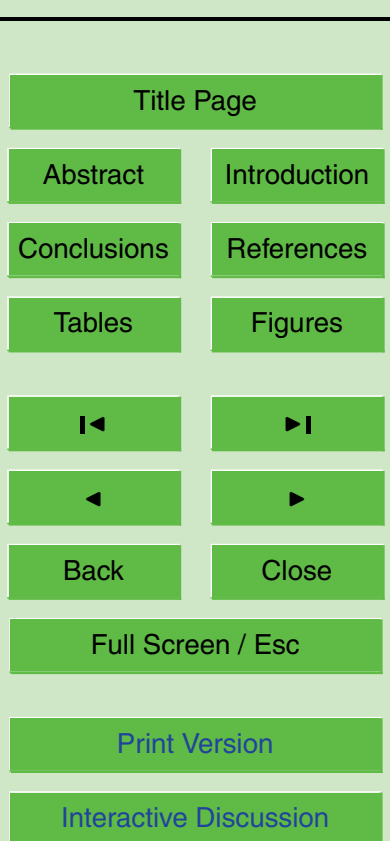




\section{HESSD}

2, 155-208, 2005

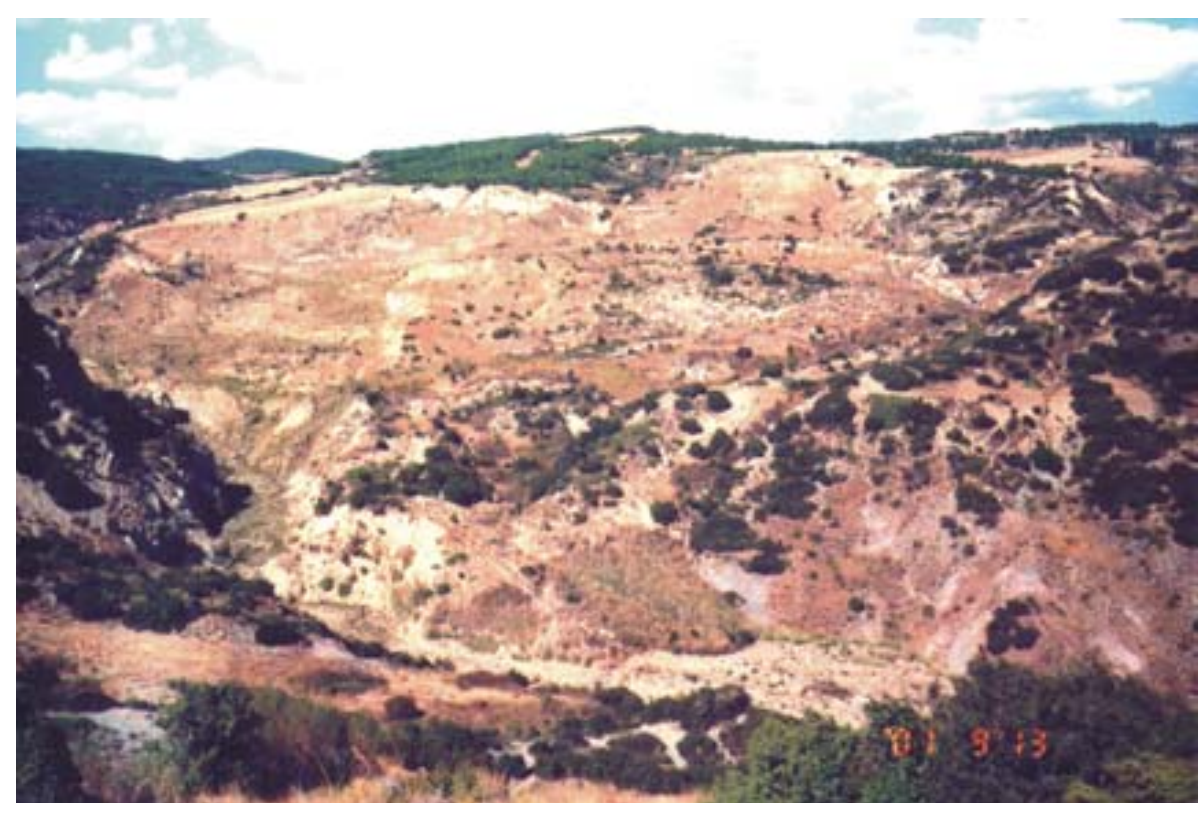

\section{Landslide} susceptibility mapping of Cekmece

T. Y. Duman et al.

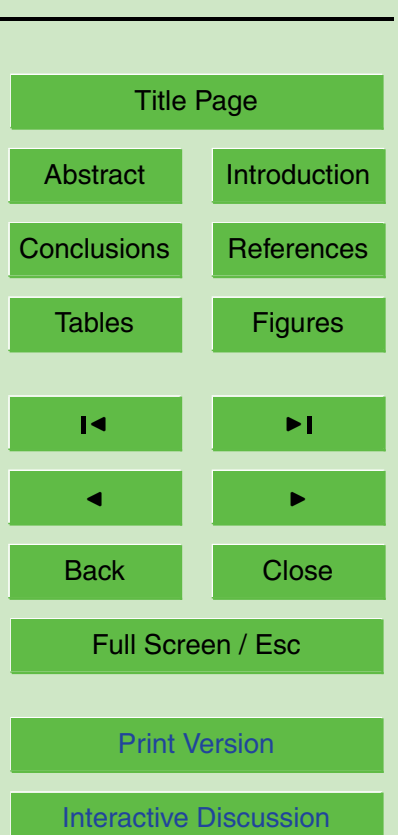

EGU 


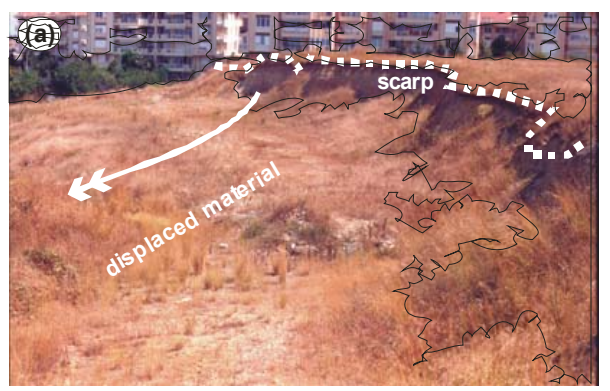

(b)

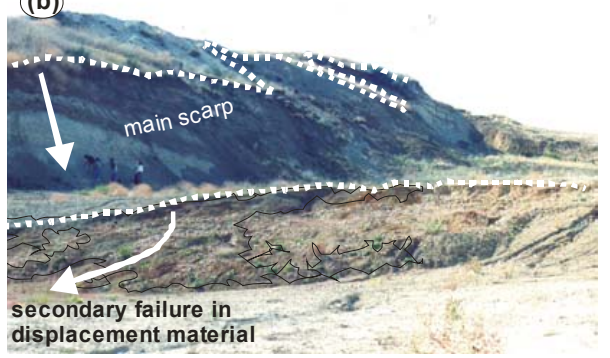

(c)

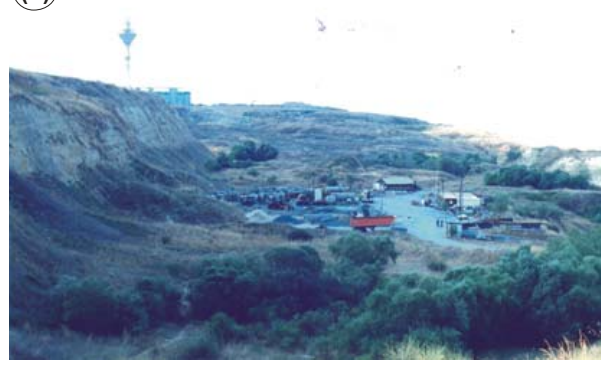

Fig. 13. Some typical views from the landslides in the area.

\section{HESSD}

2, 155-208, 2005

\section{Landslide \\ susceptibility mapping of Cekmece}

T. Y. Duman et al.

Title Page

\begin{tabular}{|c|c|}
\hline Abstract & Introduction \\
\hline Conclusions & References \\
\hline Tables & Figures \\
\hline I4 & \\
\hline & \\
\hline Back & Close \\
\hline
\end{tabular}

Full Screen / Esc

Print Version

Interactive Discussion 


\section{HESSD}

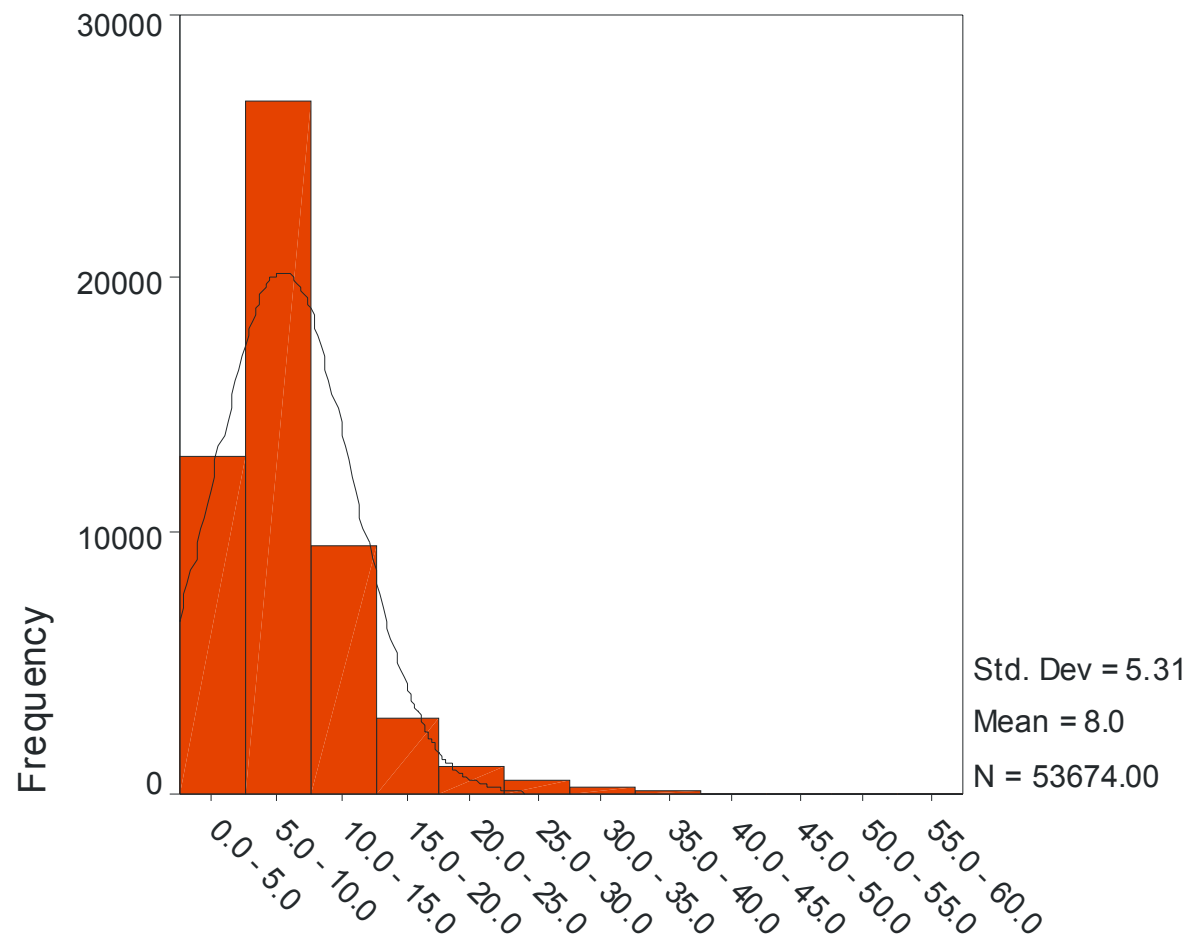

Sl ope in terval (degree) on slide mass
2, 155-208, 2005

\section{Landslide}

susceptibility mapping of Cekmece

T. Y. Duman et al.

\section{Title Page}

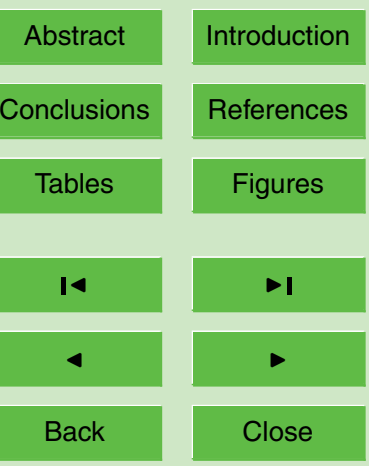

Full Screen / Esc

Print Version

Interactive Discussion

at the study area. 


\section{HESSD}

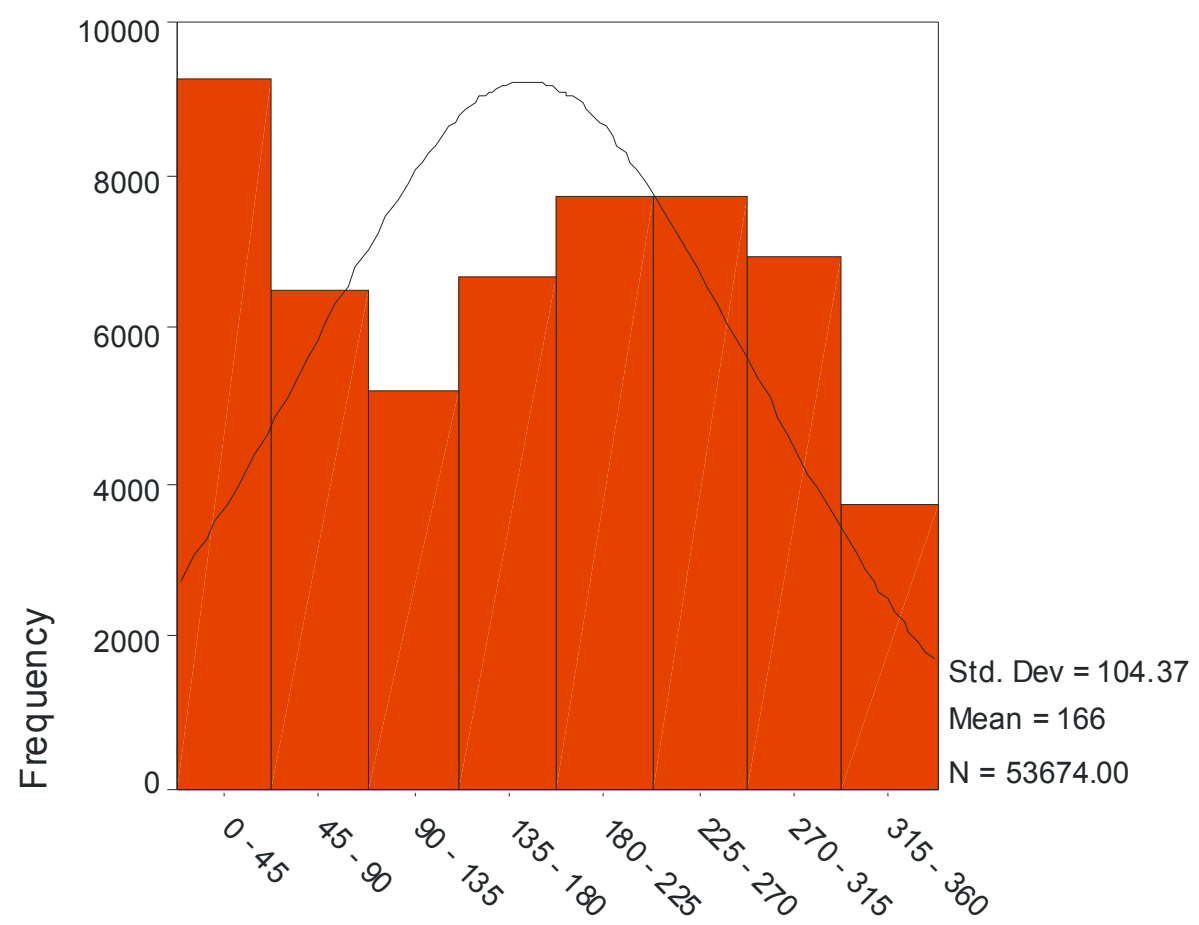

Aspect interval (degree) on slide mass
2, 155-208, 2005

\section{Landslide \\ susceptibility mapping of Cekmece}

T. Y. Duman et al.

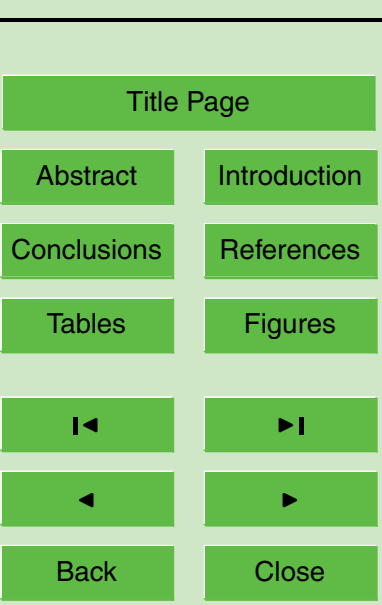

Full Screen / Esc

Print Version

Interactive Discussion

study area. 


\section{HESSD}

2, 155-208, 2005

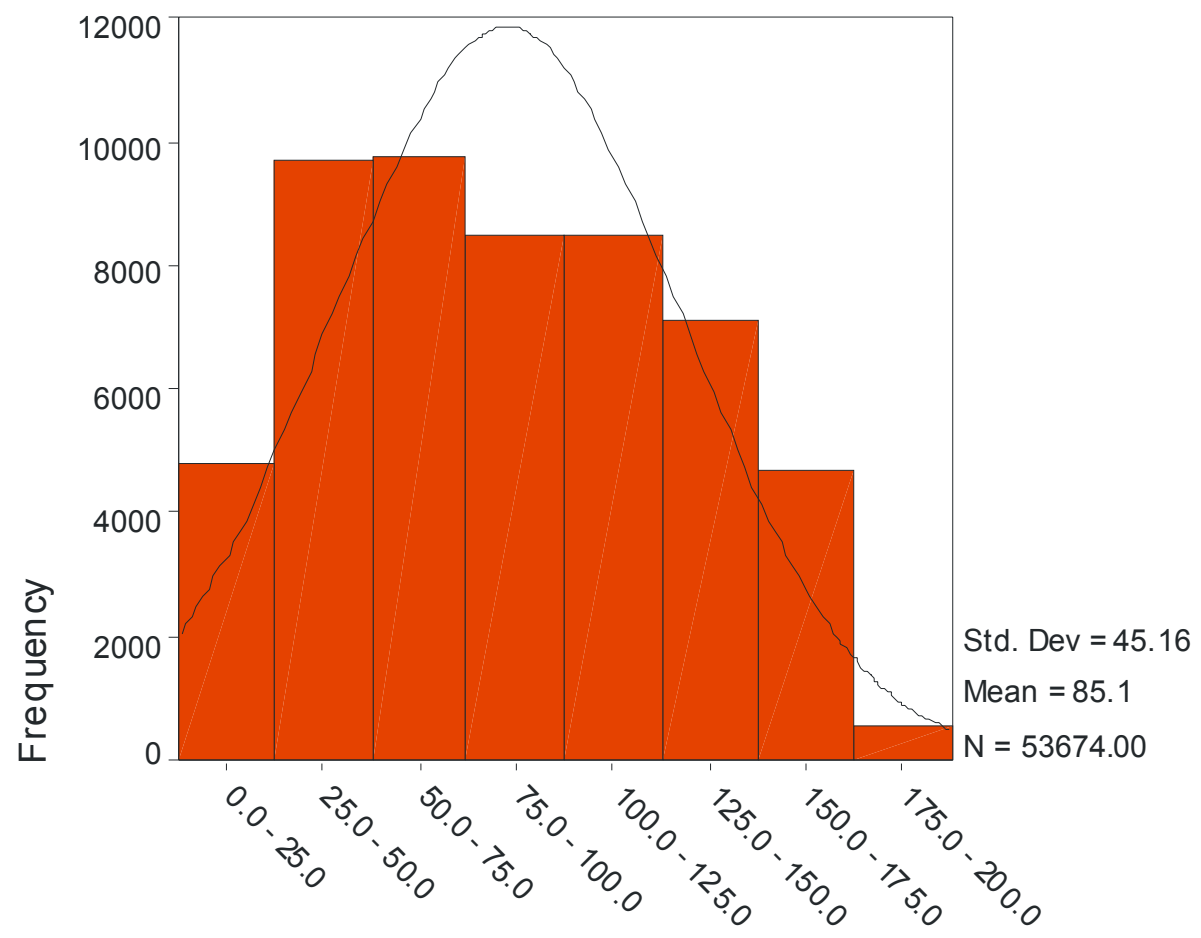

\section{Landslide}

susceptibility mapping of Cekmece

T. Y. Duman et al.

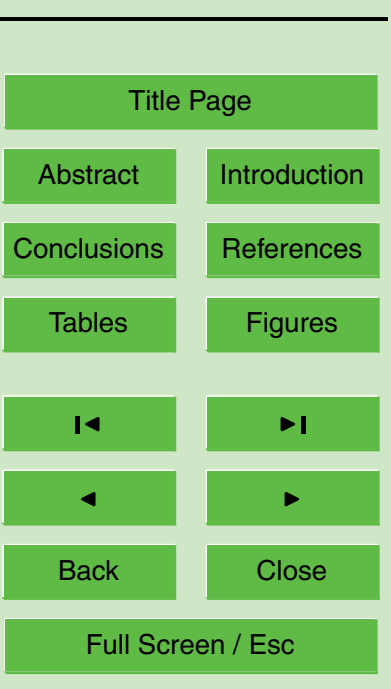

Fig. 16. Histogram illustrating the distribution of the landslides with respect to the altitude values at the study area.

Print Version

Interactive Discussion 


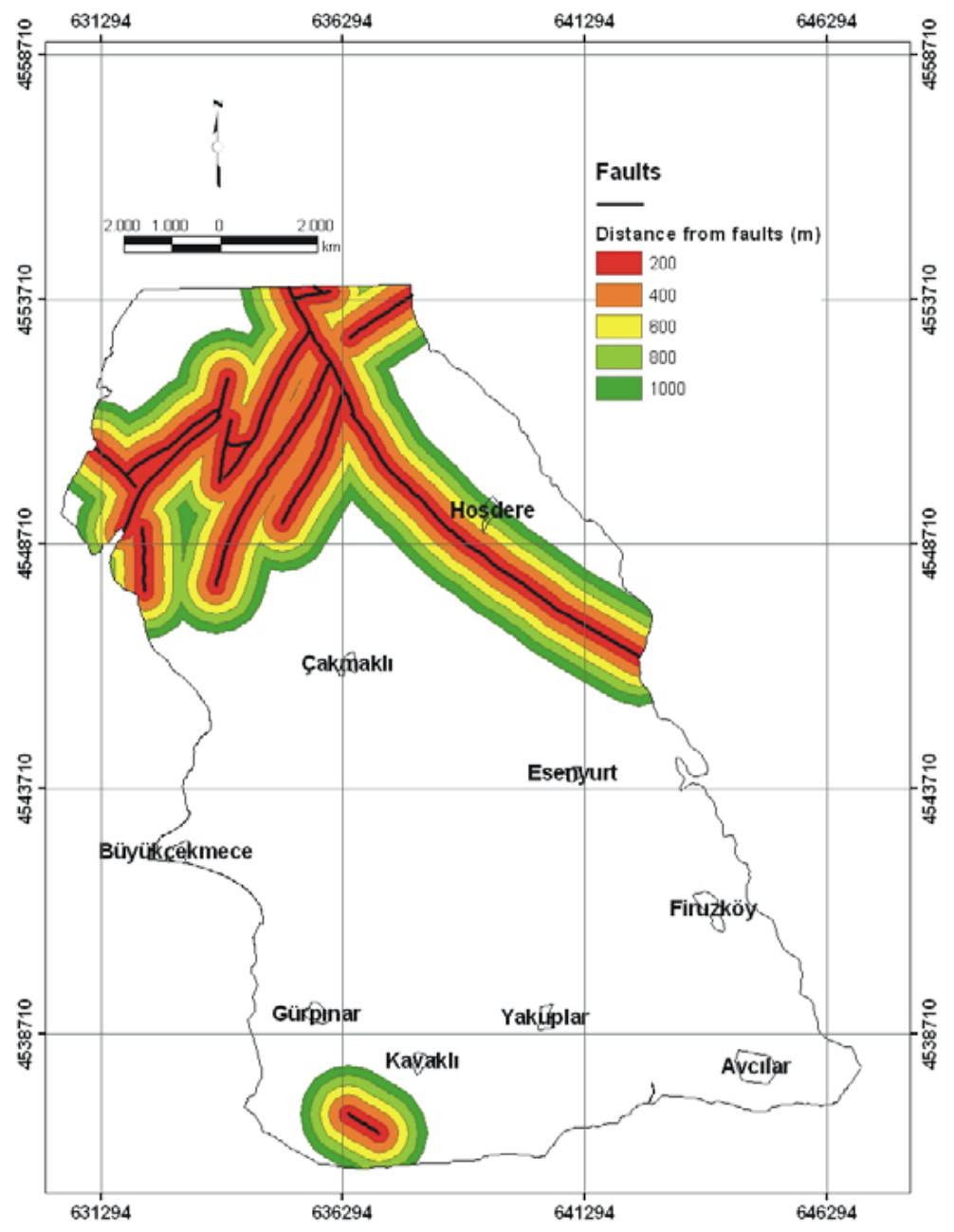

HESSD

2, 155-208, 2005

\section{Landslide susceptibility mapping of Cekmece}

T. Y. Duman et al.

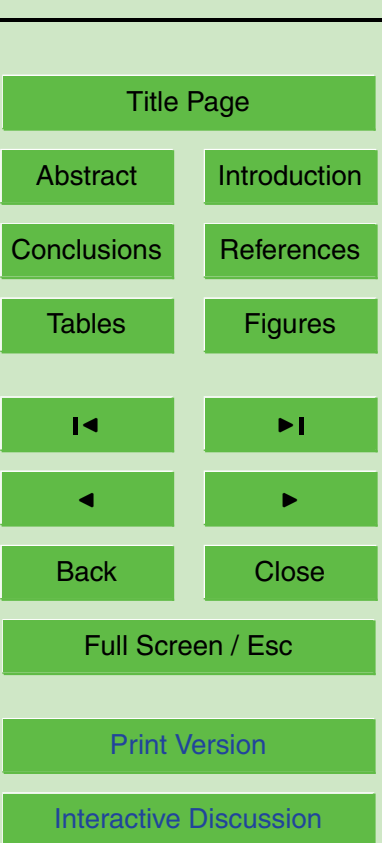

Fig. 17. The main faults and the buffer zones indicating to closeness to the faults. 


\section{HESSD}

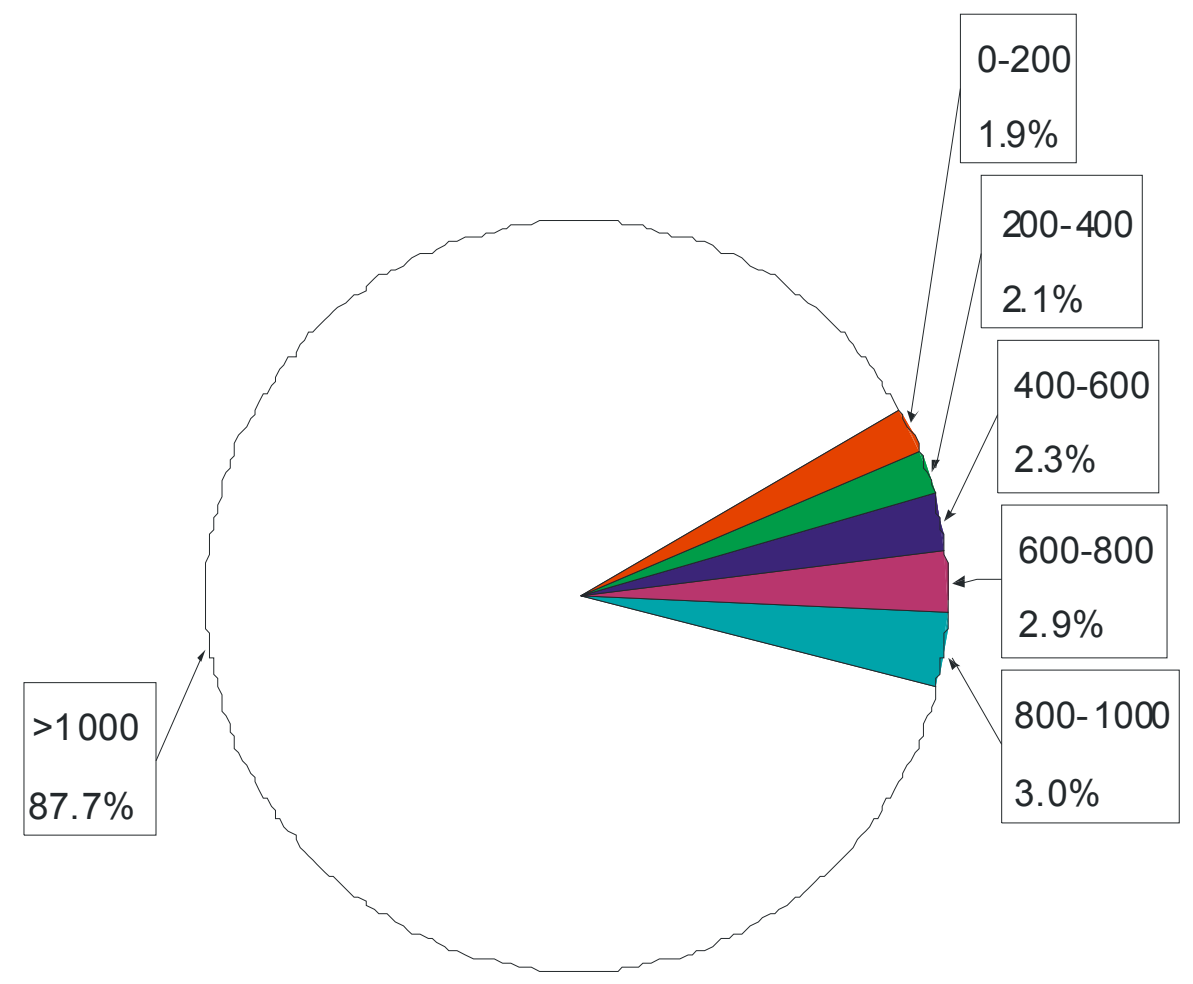

2, 155-208, 2005

\section{Landslide \\ susceptibility mapping of Cekmece}

T. Y. Duman et al.

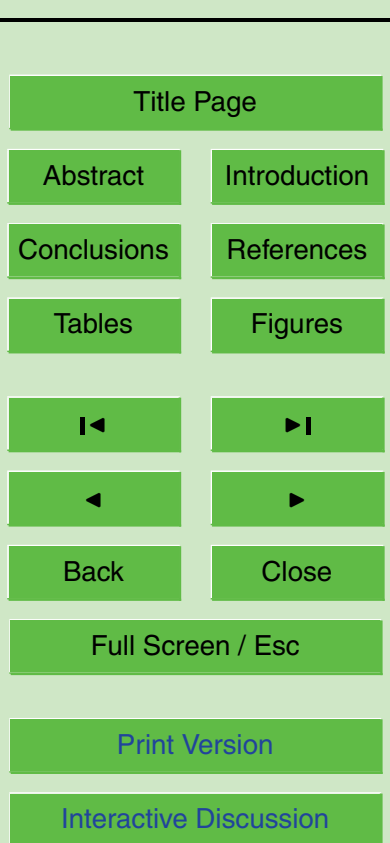

Fig. 18. Pie chart illustrating the distribution of the landslides with respect to the buffer zones indicating the closeness to the faults at the study area. 


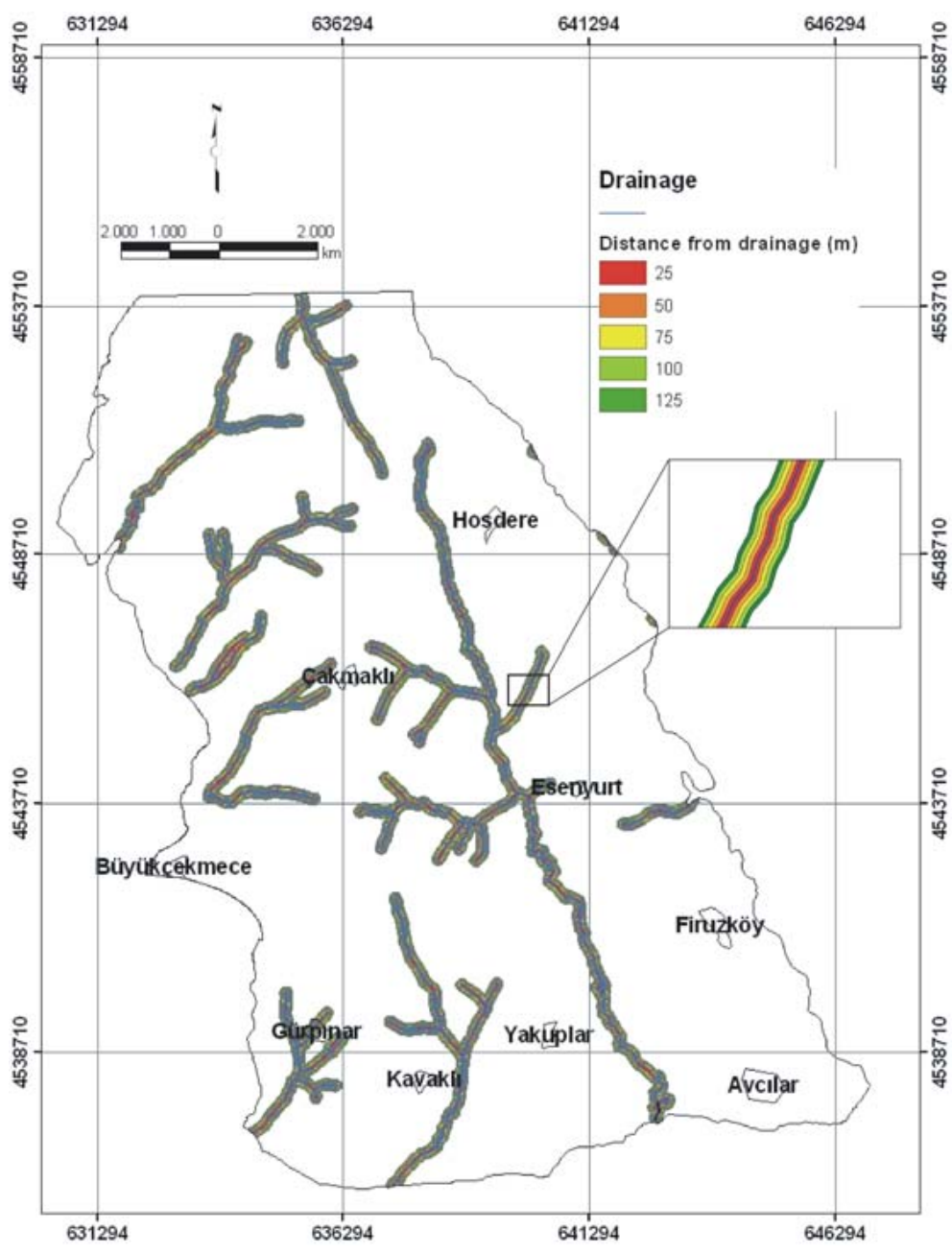

HESSD

2, 155-208, 2005

\section{Landslide susceptibility mapping of Cekmece}

T. Y. Duman et al.

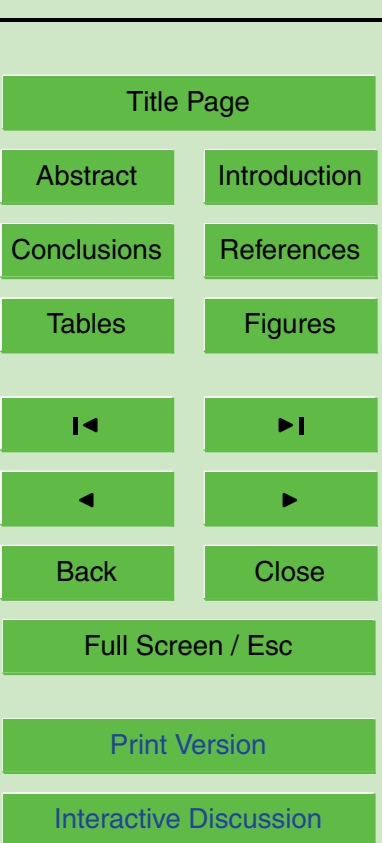

Fig. 19. The main drainage pattern and the buffer zones indicating the closeness to the drainage pattern. 


\section{HESSD}

2, 155-208, 2005

$0-25$

$2.0 \%$

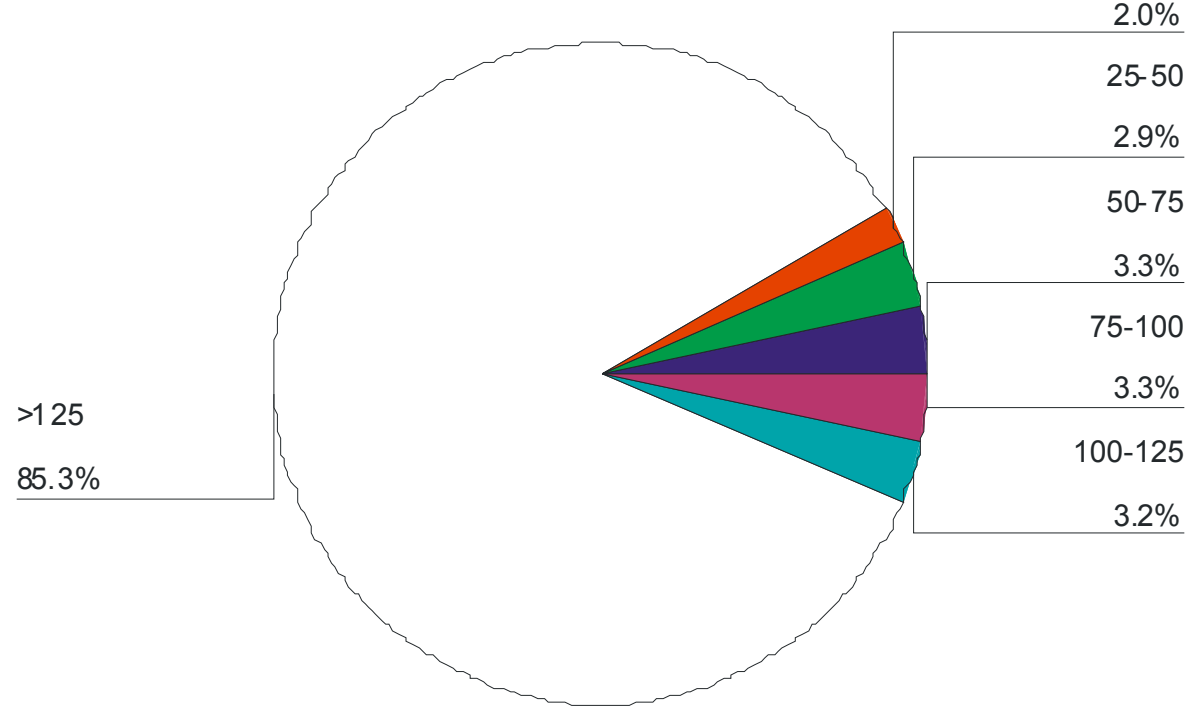

Fig. 20. Pie chart illustrating the distribution of the landslides with respect to the buffer zones indicating the closeness to the network at the study area.

\section{Landslide} susceptibility mapping of Cekmece

T. Y. Duman et al.

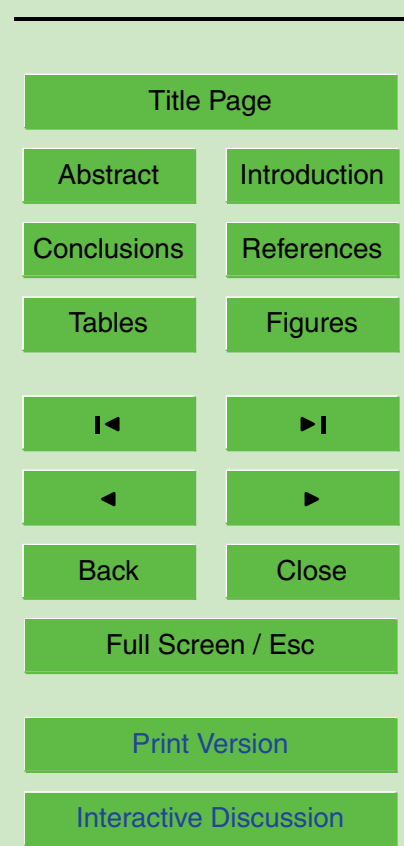




\section{HESSD}

2, 155-208, 2005

Moderate

\section{$8.8 \%$}

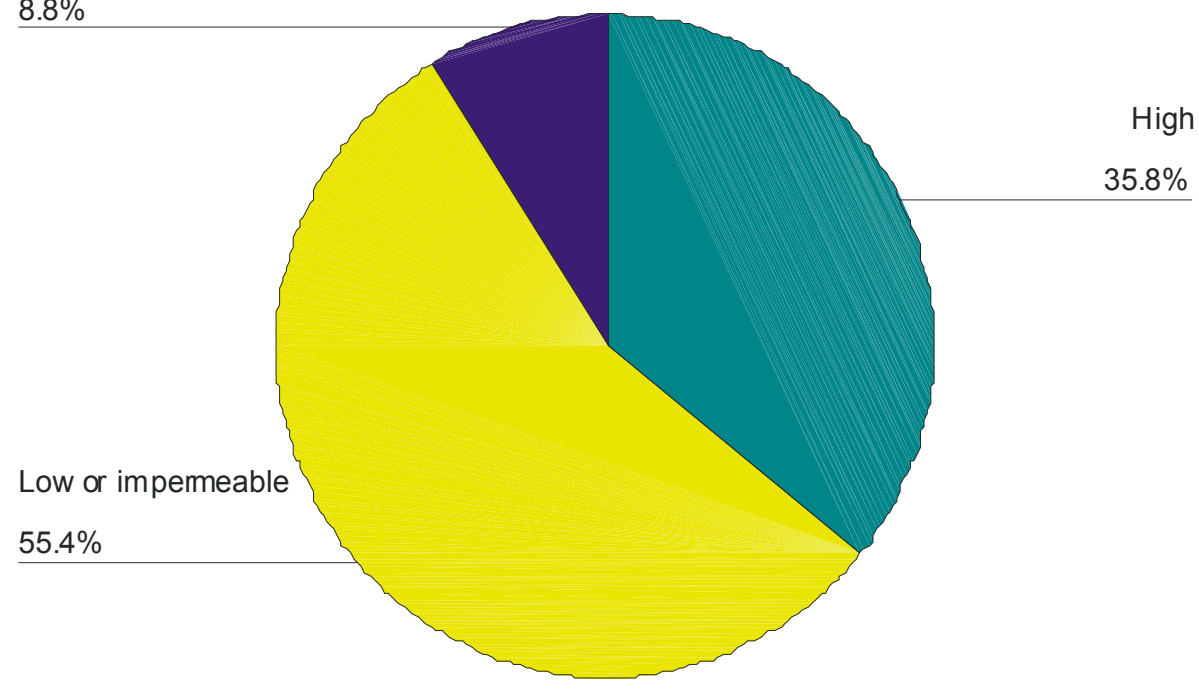

Fig. 21. Pie chart illustrating the distribution of the landslides with respect to the relative permeability classes of the lithologies network at the study area.

\section{Landslide}

susceptibility mapping of Cekmece

T. Y. Duman et al.

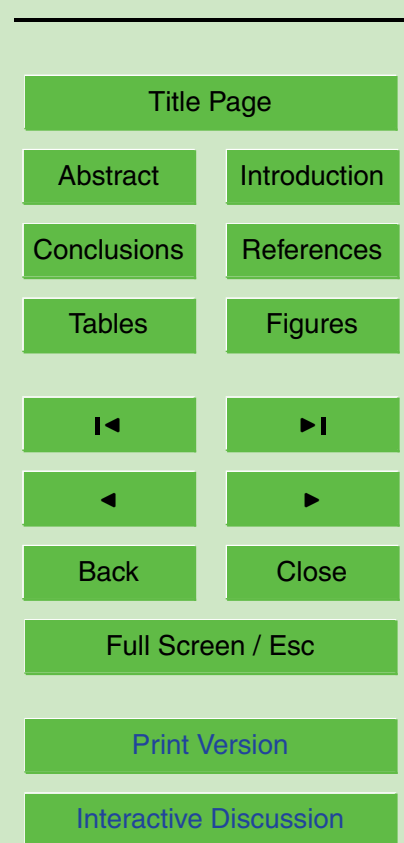




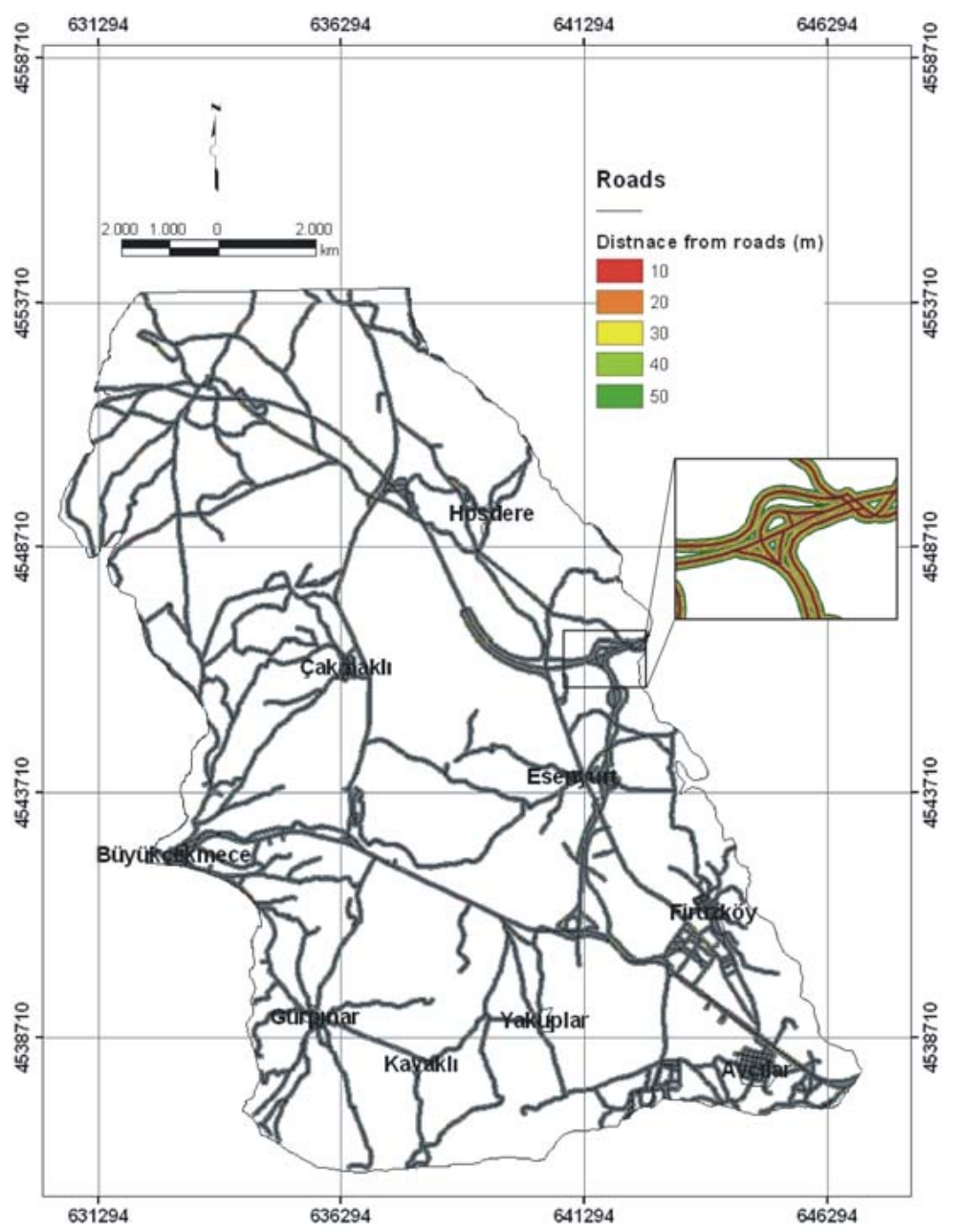

HESSD

2, 155-208, 2005

\section{Landslide susceptibility mapping of Cekmece}

T. Y. Duman et al.

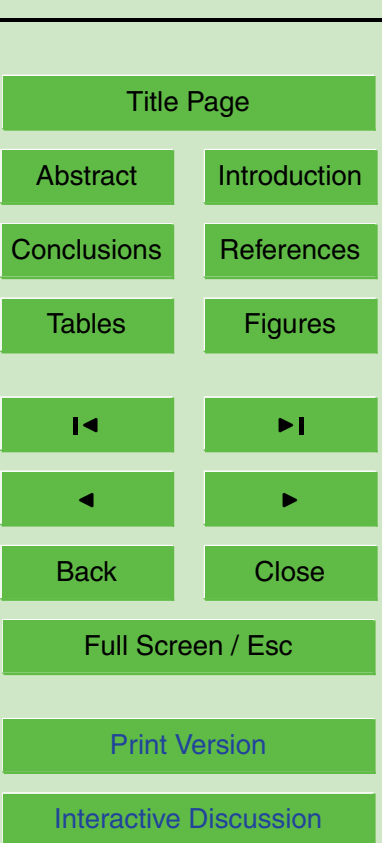

Fig. 22. The main road network and the buffer zones indicating the closeness to the main 


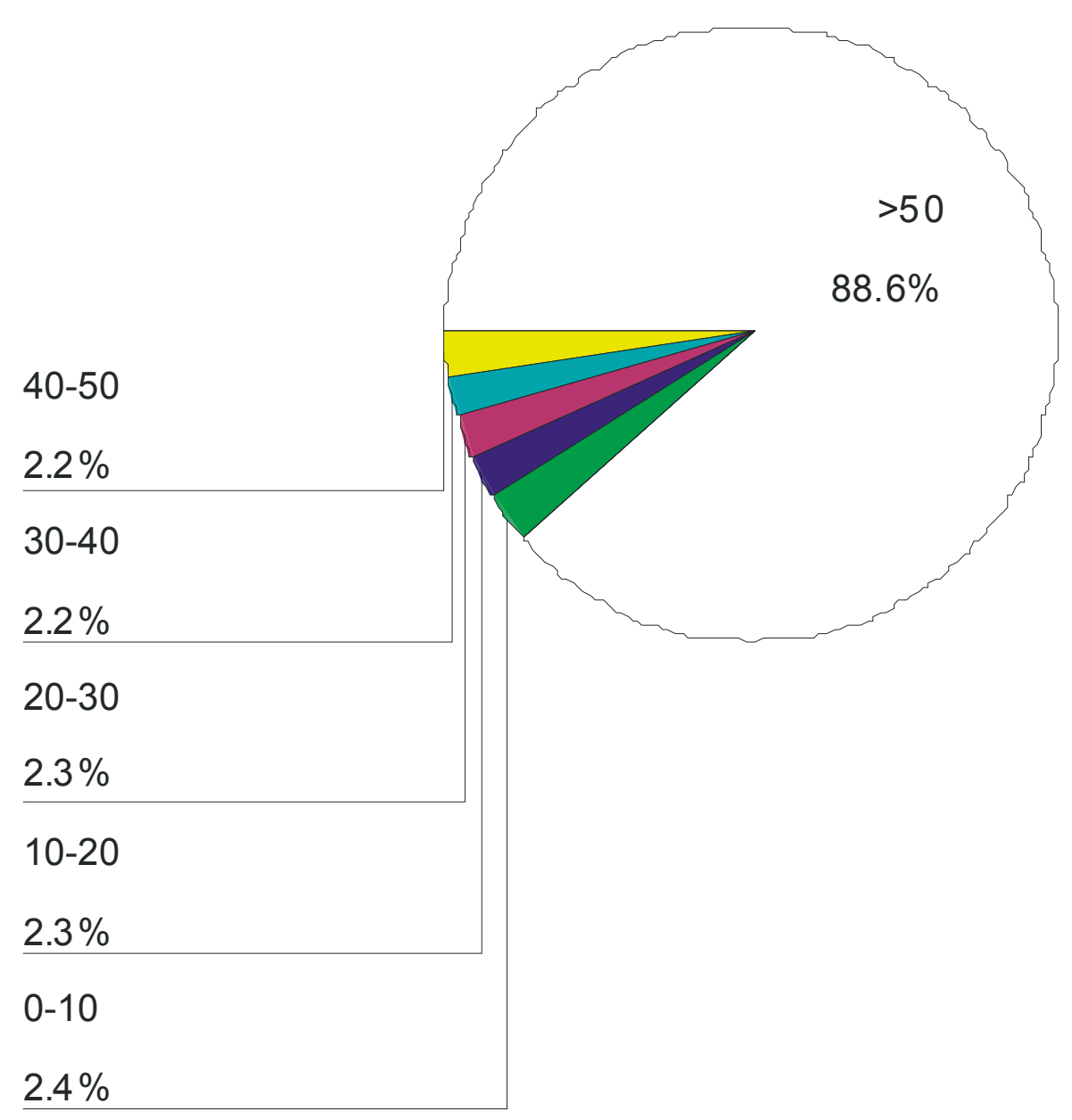

HESSD

2, 155-208, 2005

\section{Landslide \\ susceptibility mapping of Cekmece}

T. Y. Duman et al.

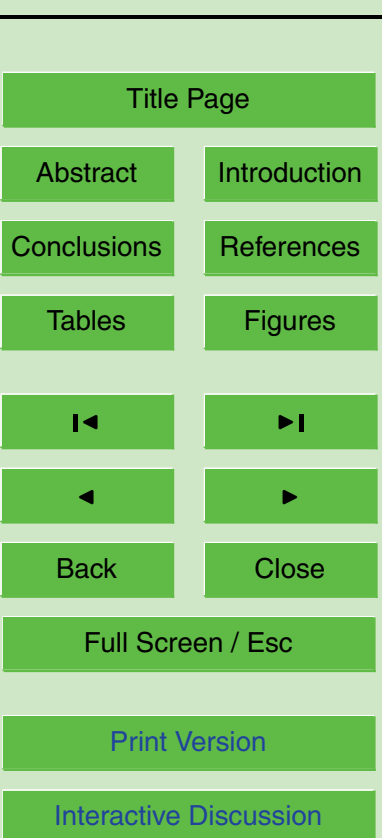

Fig. 23. Pie chart illustrating the distribution of the landslides with respect to the buffer zones indicating the closeness to the roads at the study area. 


\section{HESSD}

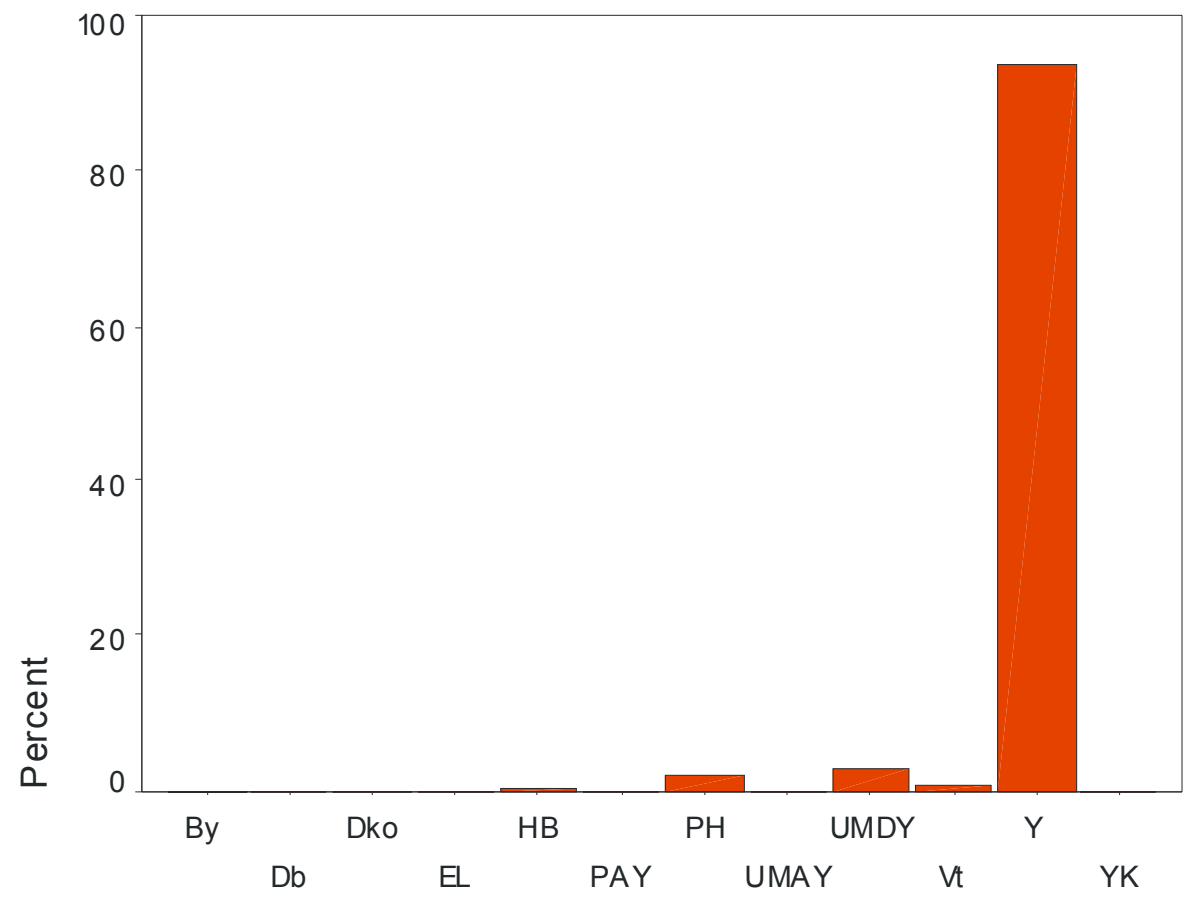

2, 155-208, 2005

\section{Landslide susceptibility mapping of Cekmece}

T. Y. Duman et al.

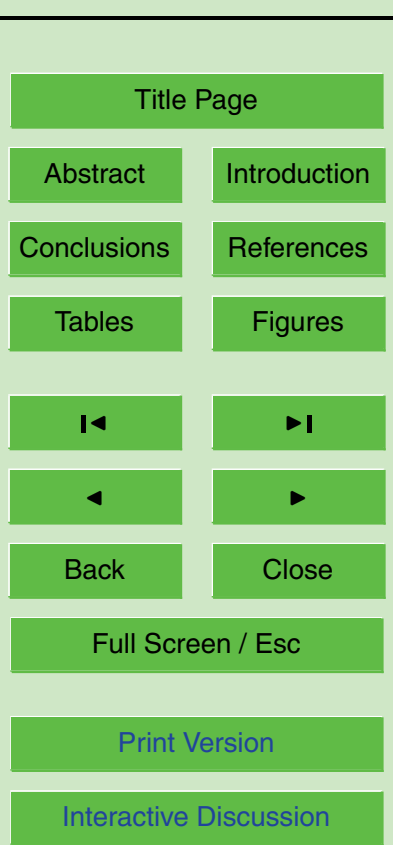

Fig. 24. Histogram illustrating the distribution of the landslides with respect to the geomorpho- 


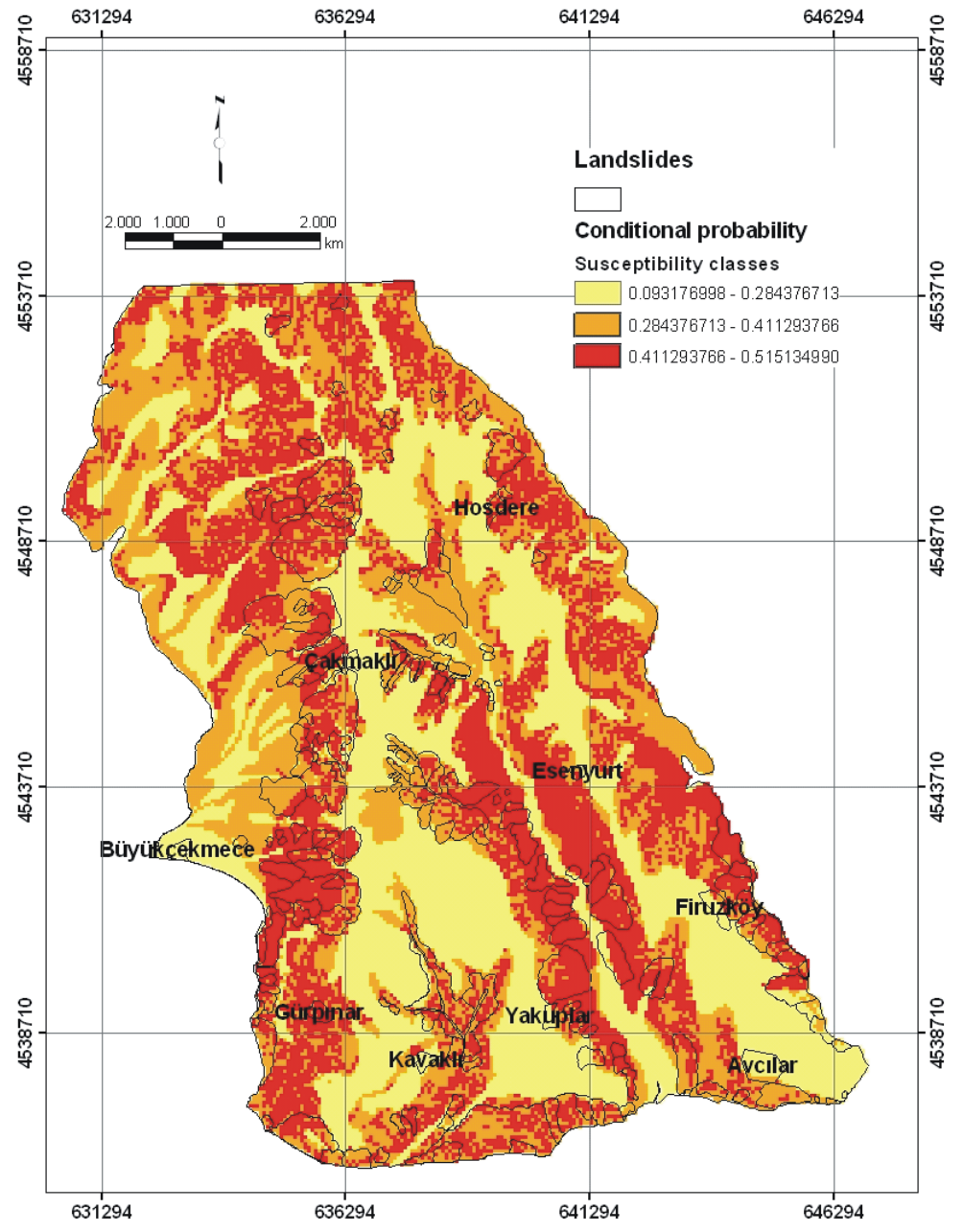

HESSD

2, 155-208, 2005

\section{Landslide susceptibility mapping of Cekmece}

T. Y. Duman et al.

Title Page

\begin{tabular}{|c|c|}
\hline Abstract & Introduction \\
\hline Conclusions & References \\
\hline Tables & Figures \\
\hline I4 & \\
\hline 4 & \\
\hline Back & Close \\
\hline
\end{tabular}

Full Screen / Esc

Print Version

Interactive Discussion

EGU 


\section{HESSD}

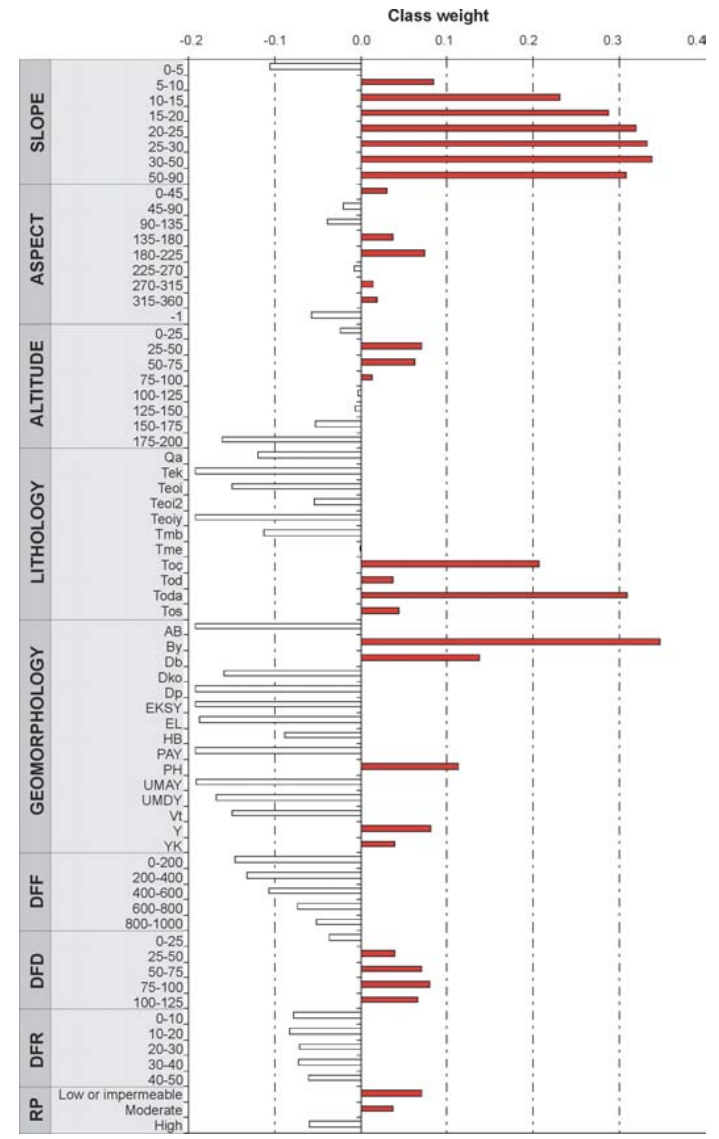

2, 155-208, 2005

\section{Landslide \\ susceptibility mapping of Cekmece}

T. Y. Duman et al.

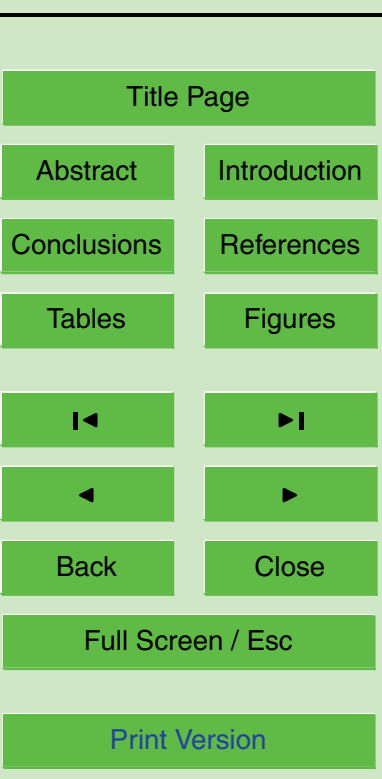

Fig. 26. Histogram showing the distribution of the weight values of the parameter classes. 


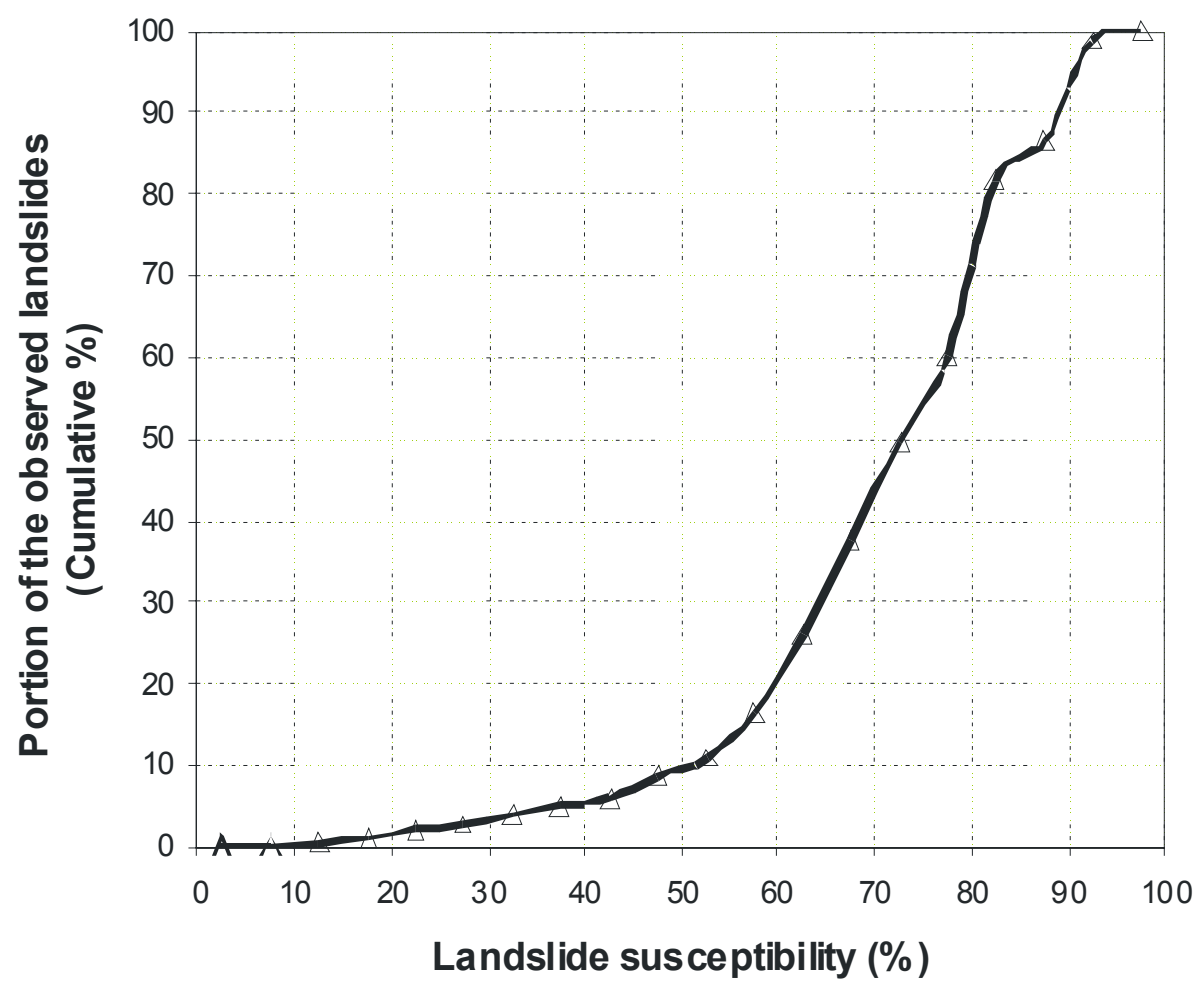

Fig. 27. Relation between the landslide susceptibility and portion of the observed landslides.

\section{Landslide} susceptibility mapping of Cekmece

T. Y. Duman et al.

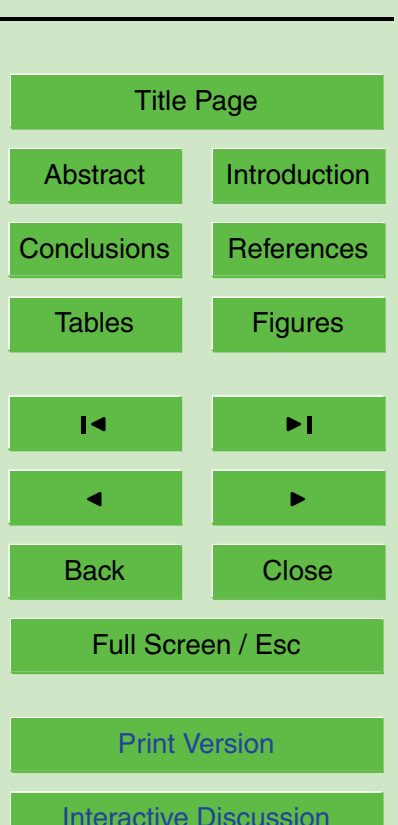

Interactive Discussion

\section{EGU}

